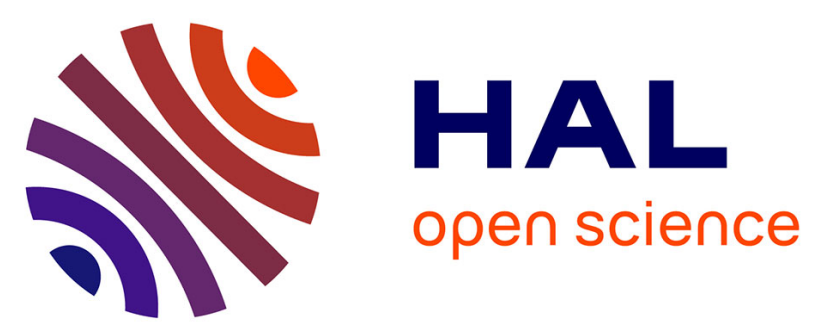

\title{
Neuropeptide Y : localization in the central nervous system and neuroendocrine functions
}

\author{
J.M. Danger, M.C. Tonon, B.G. Jenks, S. Saint-Pierre, J.C. Martel, A. Fasolo,
} Bernard Breton, R. Quirion, G. Pelletier, Hubert, Joseph, Maurice Vaudry

\section{- To cite this version:}

J.M. Danger, M.C. Tonon, B.G. Jenks, S. Saint-Pierre, J.C. Martel, et al.. Neuropeptide Y : localization in the central nervous system and neuroendocrine functions. Fundamental \& Clinical Pharmacology, 1990, 4 (3), pp.307-340. 10.1111/j.1472-8206.1990.tb00497.x . hal-02714968

\section{HAL Id: hal-02714968 \\ https://hal.inrae.fr/hal-02714968}

Submitted on 1 Jun 2020

HAL is a multi-disciplinary open access archive for the deposit and dissemination of scientific research documents, whether they are published or not. The documents may come from teaching and research institutions in France or abroad, or from public or private research centers.
L'archive ouverte pluridisciplinaire HAL, est destinée au dépôt et à la diffusion de documents scientifiques de niveau recherche, publiés ou non, émanant des établissements d'enseignement et de recherche français ou étrangers, des laboratoires publics ou privés. 


\title{
Neuropeptide $Y$ : localization in the central nervous system and neuroendocrine functions
}

\author{
JM Danger ${ }^{1}$, MC Tonon ${ }^{1}$, BG Jenks ${ }^{2}$, S Saint-Pierre ${ }^{3}$, \\ JC Martel ${ }^{4}$, A Fasolos, B Breton ${ }^{6}$, R Quirion ${ }^{4}$, \\ G Pelletier ${ }^{7}, \mathrm{H}$ Vaudry ${ }^{1 *}$ \\ 'Laboratoire d'endocrinologie moléculaire, URA CNRS 650, UA INSERM, \\ Université de Rouen, 76134 Mont-Saint-Aignan, France; \\ ${ }^{2}$ Laboratory of Animal Physiology, Catholic University, Toernooiveld, \\ 6525 ED Nijmegen, The Netherlands; \\ ${ }^{3}$ Institut National de la Recherche Scientifique (INRS Santé) and Université du Québec, \\ Pointe-Claire, Québec, Canada; \\ ${ }^{4}$ Douglas Hospital Research Centre, Department of Psychiatry, Pharmacology and Therapeutics, \\ Faculty of Medicine, McGill University, 6875 Lasalle Blvd, Verdun, Québec H4HIR3, Canada; \\ ${ }^{5}$ Dipartimento di Biologia Animale dell'Università di Torino, Turin, Italy; \\ ${ }^{6}$ Laboratoire de Physiologie des Poissons, INRA, Campus de Beaulieu, 35042 Rennes, France; \\ ${ }^{\prime}$ Laboratory of Molecular Endocrinology, Le Centre Hospitalier de l'Université Laval, \\ Boulevard Laurier, Sainte-Foy, Québec, GIV4G2, Canada
}

(Received 26 July 1989; accepted 1 December 1989)

\begin{abstract}
Summary - Neuropeptide Y (NPY) is a 36-amino acid peptide first isolated and characterized from porcine brain extracts. A number of immunocytochemical investigations have been conducted to determine the localization of NPY-containing neurons in various animal species including both vertebrates and invertebrates. These studies have established the widespread distribution of NPY in the brain and in sympathetic neurons. In the rat brain, a high density of immunoreactive cell bodies and fibers is observed in the cortex, caudate putamen and hippocampus. In the diencephalon, NPYcontaining perikarya are mainly located in the arcuate nucleus of the hypothalamus; numerous fibers innervate the paraventricular and suprachiasmatic nuclei of the hypothalamus, as well as the paraventricular nucleus of the thalamus and the periaqueductal gray. At the electron microscope level, using the pre- and post-embedding immunoperoxidase techniques, NPY-like immunoreactivity has been observed in neuronal cell body dendrites and axonal processes. In nerve terminals of the hypothalamus, the product of the immunoreaction is associated with large dense core veșicles. In lower vertebrates, including amphibians and fish, neurons originating from the diencephalic (or telencephalic) region innervate the intermediate lobe of the pituitary where a dense network of immunoreactive fibers has been detected. At the ultrastructural level, positive endings have been observed in direct contact with pituitary melanotrophs of frog and dogfish. These anatomical data suggest that NPY can act both as a neurotransmitter (or neuromodulator) and as a hypophysiotropic neurohormone.
\end{abstract}

\footnotetext{
* Correspondence and reprints
} 
In the rat a few NPY-containing fibers are found in the internal zone of the median eminence and high concentrations of NPY-like immunoreactivity are detected in the hypothalamo-hypophyseal portal blood, suggesting that NPY may affect anterior pituitary hormone secretion. Intrajugular injection of NPY causes a marked inhibition of LH release but does not significantly affect other pituitary hormones. Passive immunoneutralization of endogenous NPY by specific NPY antibodies induces stimulation of LH release in female rats, suggesting that NPY could affect LH secretion at the pituitary level. However, NPY has no effect on LH release from cultured pituitary cells or hemipituitaries. In addition, autoradiographic studies show that sites for ${ }^{125}$ I-labeled Bolton-Hunter NPY or ${ }^{125}$ I-labeled PYY (2 specific ligands of NPY receptors) are not present in the adenohypophysis, while moderate concentrations of these binding sites are found in the neural lobe of the pituitary. It thus appears that the inhibitory effect of NPY on LH secretion must be mediated at the hypothalamic level. This hypothesis is supported by the following observations: $\mathrm{i}$ ), intracerebroventricular injection of NPY causes a reduction in plasma LH; ii), NPY fibers have been observed in contact with LHRH neurons in the preoptic region; iii), the organum vasculosum of the lamina terminalis, where LHRH neurons are located, lacks a blood-brain barrier (NPY injected peripherally can thus reach LHRH neurons in this area). The fact that intracerebroventricular injection of NPY in 5,7-dihydroxytryptamine treated rats causes stimulation of $\mathrm{LH}$ release (instead of an inhibition in control animals) also suggests that the effect of NPY may in part be mediated via serotoninergic neurons.

In amphibians, the existence of a NPY-neuronal system originating from the hypothalamus and terminating in the pars intermedia suggest that NPY may play a role in the control of pituitary melanotrophs. In vitro data show that NPY induces a marked inhibition of $\alpha$-melanotropin ( $\alpha$-MSH) release in frog and toad. The biologically active determinant of NPY is located in the C-terminal region of the molecule. Experiments conducted with acutely dispersed pituitary cells and electrophysiological data using the patch-clamp technique indicate that NPY exerts a direct effect on pituitary melanotrophs. Administration of NPY in black background-adapted toads causes aggregation of dermal melanophores. Taken together, these data indicated that in amphibians NPY can be considered as a melanotropin-release inhibiting factor (MIF).

From these studies, it is concluded that NPY was: i), a neurotransmitter which mediates a number of processes in the brain and in sympathetic nerves; and ii), a hypophysiotropic neurohormone which regulates the secretion of various pituitary hormones such as LH in mammals and $\alpha-\mathrm{MSH}$ in amphibians.

neuropeptide $\mathbf{Y}$ / immunocytochemistry / neuroendocrinology / gonadotropin-releasing hormone (LHRH) / melanocyte-stimulating hormone ( $\alpha$-MSH) / luteinizing hormone / pituitary / anterior lobe / intermediate lobe

\section{Introduction}

Besides classical neurotransmitters, several regulatory neuropeptides act as chemical messengers of cell communication. These peptides are usually synthesized as precursor proteins which are further cleaved by proteolytic enzymes. Processing of pro-peptides also includes various post-translational modifications such as glycosylation, phosphorylation, amidation and acetylation (Jenks et al, 1986). Following their release, regulatory peptides interact with specific receptors which are generally located on the membrane of the target tissue. This interaction triggers a series of intracellular events which induce the physiological response. Owing to 
their variety, their broad distribution and their various physiological activities, regulatory peptides are now considered as key molecules of neuronal communication. During the past 2 decades, intensive research has been conducted in order to identify and localize biologically active peptides in the brain and to determine the precise functions of these neuropeptides.

Among the neuropeptides discovered recently, neuropeptide tyrosine (NPY) has raised considerable interest. NPY belongs to a family of peptides including peptide tyrosine-tyrosine (PYY) and pancreatic peptides (PP) which exhibit close structural homologies with NPY. Avian pancreatic polypeptide (APP) was the first PP-related peptide to be discovered (Kimmel $e t$ al, 1975). APP is a 36-amino acid peptide which was initially isolated from chicken pancreatic extracts as a sideproduct of insulin purification (Kimmel et al, 1975). Homologous peptides have been subsequently characterized in the islets of Langerhans of several mammalian species (Lin and Chance, 1972; 1974; Schwartz and Tager, 1981 ; Boel et al, 1984; Schwartz and Hansen, 1984; Yamamoto et al, 1986). All these peptides are composed of 36-animo acid residues and their primary structure has been highly preserved during evolution.

A number of gut or pancreatic peptides have also been detected in the brain. For instance, vasoactive intestinal peptide (VIP), cholecystokinin (CCK) and neurotensin were initially isolated in the digestive tract and have been subsequently detected in specific neurons of the central nervous system (Vanderhaeghen et al, 1975; Hökfelt et al, 1982). As expected, immunohistochemical techniques using APP-directed antibodies have revealed an extensive PP-like neuronal system in rat and human brain. It has thus been established that the brain of mammals contain a PP-related peptide (Loren et al, 1979; Lundberg et al, 1980; Hunt et al, 1981 ; Card and Moore, 1982; Card et al, 1983). However the attempts to characterize the immunoreactive peptide by means of radioimmunoassays for APP have led to inconsistent results. Despite the intensive staining observed by immunocytochemistry, only traces of immunoreactive material could be detected by radioimmunological techniques (Lundberg et al, 1984).

Since many gut peptides appear to possess a carboxyterminal tyrosine-amide residue, Tatemoto and Mutt have developed an original chemical method for the detection of such $\mathrm{Tyr}-\mathrm{NH}_{2}$-terminated peptides (Tatemoto and Mutt, 1982). Using this approach, these authors have isolated from the porcine gut a new peptide exhibiting high homology with the PP family. This peptide with tyrosine residues at both amino- and carboxyterminal ends was named peptide YY (PYY). Thus, PYY became a good candidate for the PP-like immunoreactivity previously reported in the brain. However, the same year, Tatemoto et al (1982) isolated and characterized a new peptide of the PP/PPY family in porcine brain extracts. This brain peptide was named neuropeptide tyrosine or NPY.

As with PPY, NPY is 36-amino acid peptide and has a C-terminal tyrosine amide residue. The NPY molecule exhibits 5 tyrosines in positions $1,20,21,27$, 36. The primary structure has been determined in 5 mammalian species, ie hog, 
rat (Allen et al, 1987; Larhammar et al, 1987), man (Corder et al, 1984; Minth et al, 1986), guinea pig and rabbit (O'Hare et al, 1988). The sequence of NPY in rabbit, guinea pig and man is identical to that of rat NPY and only differs from the porcine sequence by the substitution of a leucine residue by a methionine in position 17. Computer-assisted analysis has revealed that the spatial structure of NPY consists of 2 main domains: the $\mathrm{N}$-terminal portion has a $\beta$-turn-like structure and the $\mathrm{C}$-terminal region is organized as a $\beta$-helix (Allen et al, 1987). Owing to the structural homologies with PP-related peptides, NPY has been classified within the PP-family. NPY exhibits a high degree of sequence homology with porcine PYY and PP (61 and 47\%, respectively). Phaeochromocytomal tissues are generally rich in NPY material (Emson et al, 1984). As a matter of fact, Corder et al, (1984) have succeeded in isolating and characterizing human NPY from adrenal medullary tumors. These adrenal medulla tumors have also been used as a source of messenger RNA encoding NPY to synthesize and clone the corresponding complementary DNA (Minth et al, 1984). Translation of the encoding region gives rise to a pro-peptide of 97 -amino acid residues with a molecular weight of $10.9 \mathrm{kDa}$. The genes encoding man (Minth et al, 1986) and rat (Allen et al, 1987; Larhammar et al, 1987) NPY have subsequently been isolated, cloned and sequenced. Comparison of the human and rat pro-hormones reveals the presence of 4 substitutions ( 2 of which are located in the signal peptide and the others in the flanking peptide). An additional methionyl residue is also present at the $\mathrm{N}$-terminal end of the human pre-pro-molecule.

The various steps of the translational processing of NPY are now well known. The signal peptide is first removed co-translationally. Then, the pro-peptide is cleaved at the level of a pair of basic amino-acids $\left(\mathrm{Lys}_{66}-\mathrm{Arg}_{67}\right)$ to generate an intermediate product (NPY-Gly $37-\mathrm{Lys}_{38}-\mathrm{Arg}_{36}-\mathrm{COOH}$ ) and a 30-amino acid peptide named $\mathrm{C}$-terminal flanking peptide of neuropeptide tyrosine (C-PON). The Arg- and Lys-residues of the intermediate peptide product are cleaved by a carboxypeptidase and NPY is amidated by a peptidyl glycine alpha-amidating monooxygenase, the $\mathrm{Gly}_{37}$ residue as an amine donor.

In rat and in man, the gene encoding NPY consists of 4 exons and 3 introns. The first exon encodes for the 5'-unstranslated region and for the methionine codon necessary to initiate translation. The second exon encodes for the remainder of the signal peptide and for most of the peptidic sequence of NPY. The third exon encodes for the C-terminal tyrosine and its site of amidation and in addition, for the 23 first amino acids of the C-PON molecule. Finally, the 3 rd exon encodes for the 7 last amino-acids of C-PON and for the 3'-untranslated region.

The gene encoding NPY is located on chromosone 7 (Takeuchi et al, 1986). In Sprague-Dawley rats, there is only one gene coding for NPY; however, there is evidence of polymorphism in allelic genes. In fact when the allelic genes are compared, 8 modifications are noted, but none is found in the exons (Allen et al, 1987). 


\section{Localization of NPY in the central nervous system}

In mammalian brain, the concentrations measured by means of radioimmunoassay are in the range of one picomol per mg wet tissue (YS Allen et al, 1983; Dawbarn et al, 1984; DeQuidt and Emson, 1986). The highest concentrations are found in the paraventricular and arcuate nucleus of the hypothalamus. High amounts of NPY-like material have also been measured in the paraventricular nucleus of the thalamus, the nucleus accumbens, the septum and medial amygdala (YS Allen et al, 1983; Dawbarn et al, 1984). Concurrently, very low amounts of NPY have been detected in the cerebellum (Lundberg et al, 1984). In the medulla, the concentrations of NPY are higher in the sacral region than in lumbar, thoracic or cervical segments (Gibson et al, 1984).

The localization of NPY-containing neurons in the brain of mammals has been intensively studied. In the rhinencephalon, NPY perikarya are mainly located in the anterior and medial olfactory nuclei (Chronwall et al, 1985; Gall et al, 1986). Most of these neurons are multipolar with short processes. They are generally located in the deep granular cell layer or in the gray matter, in the vicinity of the ependymal zone (Scott et al, 1987).

In the telencephalon, all subdivisions of the cerebral cortex contain NPY fibers (figure 1). The distribution of NPY immunoreactivity in the visual cortex has been

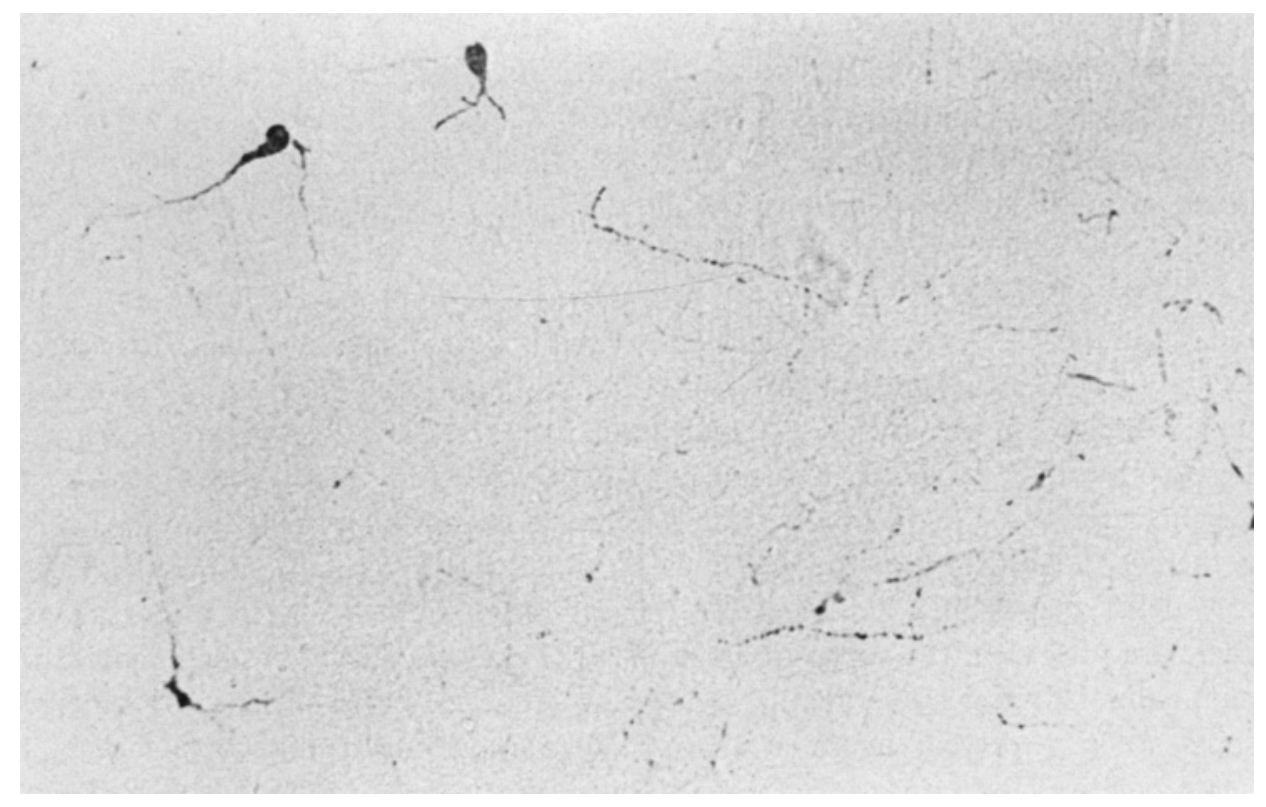

Fig 1. Section through the rat cerebral cortex. Several cell bodies and beaded fibers are labelled by the NPY antiserum $(\times 200)$. 
thoroughly studied in various species including rat (Chronwall et al, 1984), cat (Wahle et al, 1986), monkey (Hendry et al, 1984a, b) and man (Van Reeth et al, 1987). Immunopositive perikarya are numerous in cortical layers II, III, V and VI. NPY-containing fibers are also present in all cortical layers, but the density of nerve processes is greater in neocortical layers I and IV. In layer I, the fibers are often seen in the vicinity of cerebral arteries, suggesting that NPY may play a role in the regulation of cerebral blood flow. Immunoreactive cell bodies are also located in other telencephalic areas such as the hippocampus and striatum. The distribution of NPY immunoreactive neurons has been determined in the hippocampus of rat (Köhler et al, 1987), monkey (Köhler et al, 1986a) and man (Chan-Palay, 1987). A relatively high density of immunoreactive cell bodies is located in the internal regions of Ammon's horn. The subiculum also contains numerous NPY-neurons. These cell bodies are primarily located in the pyramidal cell layer.

In the subiculum and Ammon's horn, NPY-nerve processes are mainly found in the molecular layer; immunopositive fibers are particularly dense in the entorhinal area where some large multipolar and bipolar cells are present in the deep layers (IV-VI). Immunohistochemical techniques have also revealed the presence of NPY perikarya in the caudate and putamen nuclei, the claustrum, the endopiriform and accumbens nuclei (Massari et al, 1984; Kerkérian et al, 1986) and in the dorso-lateral septum (Gaspar et al, 1987). In the amygdala, NPY cells are located in the basolateral and medial nuclei. The whole amygdala contains NPY-nerve processes. The density of fibers is, however, higher in the central nucleus of the amygdala (Gustafson et al, 1986).

In the diencephalon of all species studied, such as hamster (Sabatino et al, 1987), dogfish (Vallarino et al, 1988), goldfish (Pontet et al, 1989), trout (Danger et al, submitted), frog (Danger et al, 1985; Caillez et al, 1987a, b), newt (Perroteau et al, 1988), rat (Chronwall et al, 1984; Everitt et al, 1984; Pelletier et al, 1984b), cat (Wahle et al, 1986; Léger et al, 1987; Hu et al, 1987), monkey (Smith et $a l, 1985$; Bons et al, submitted) and man (Pelletier et al, 1984a; Chan-Palay and Yasargil, 1986), the arcuate nucleus of the hypothalamus contains the highest density of NPY-neuronal systems (figs 2-4). In the rat brain, cell bodies have also been visualized in the dorsal and dorsolateral preoptic area. However, in the cat the preoptic hypothalamus does not contain any NPY-immunoreactive perikarya (Léger $e t$ al, 1987). The paraventricular, periventricular and arcuate nuclei, as well as the preoptic portion of the bed nucleus of the stria terminalis contain particularly dense plexus of NPY-fibers. In the cat brain, only a few immunoreactive fibers are present in the suprachiasmatic area (Léger $e t a l, 1987)$ whereas in other mammalian species, numerous nerve processes innervate this nucleus. NPY-nerve fibers are also present in the neurovascular part of the median eminence and scarce positive fibers are observed in the posterior lobe of the pituitary (Pelletier et al, 1984b). In the thalamus, a relatively high density of NPY-perikarya and nerve fibers is found in the geniculate nucleus. The cell bodies are mainly located 


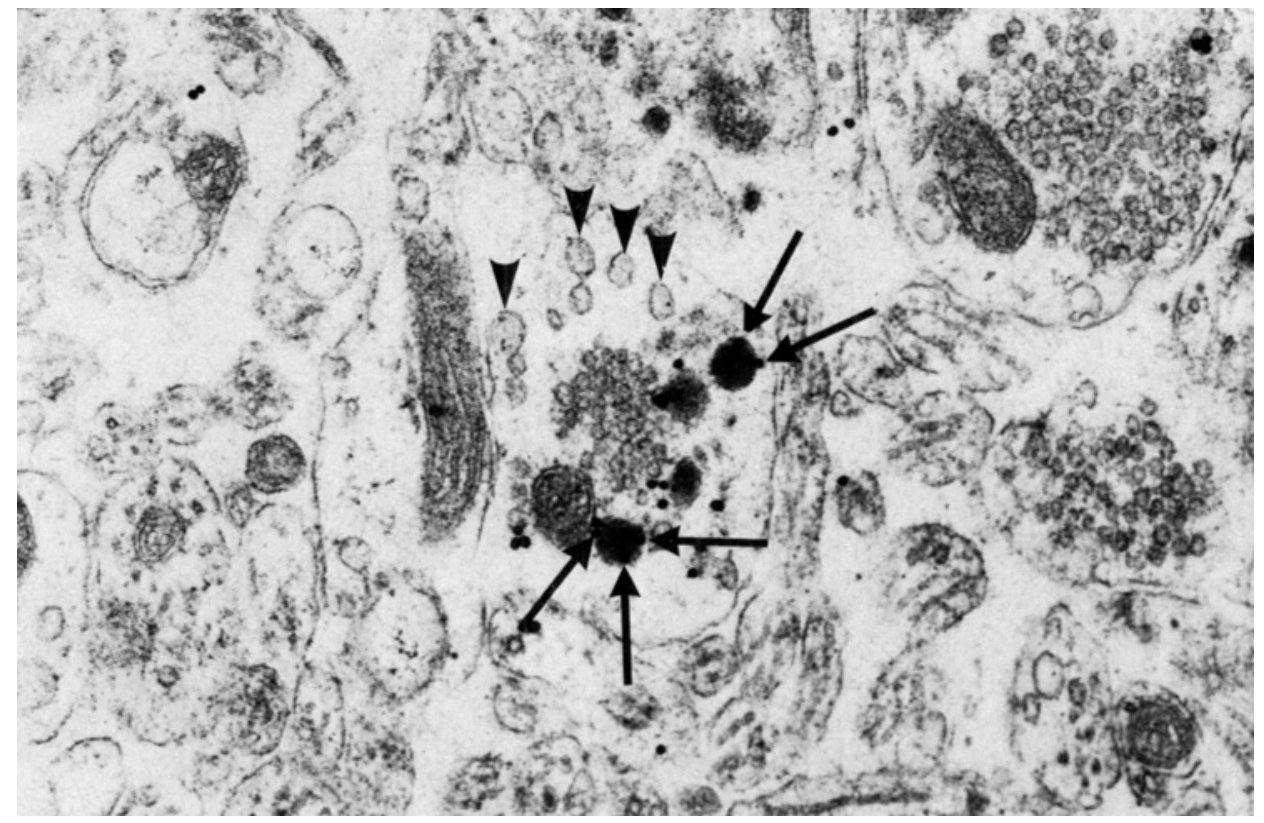

Fig 2. Immunoelectron microscopic localization of NPY in the frog brain using the peroxidase-antiperoxidase method. One positive terminal of the infundibulum is immunostained. The gold particles are located in dense core vesicles (arrows). Note that clear vesicles are unstained (arrowheads); $(\times 55,000)$. (From Danger JM et al, Peptides 6, 1225-1236, 1985; With permission).

in the areas known to receive contralateral retinal afferences such as the anteroexternal part of the ventro-lateral geniculate body. In addition, NPY-positive cell bodies and nerve fibers are present in the intergeniculate leaflet (Moore et al, 1984; Ueda et al, 1986; Sabatino et al, 1987). NPY containing neurons are also located in other thalamic nuclei such as the pretectal oliva and the habenula (Smith et al, 1985).

In the mesencephalon of rats, NPY-positive perikarya are located in the ventral tegmentum, the pars compacta of the substantia nigra, the laterocentral gray matter, the reticular formation, and in dorsal and lateral inferior colliculi (Everitt et al, 1984; Chronwall et al, 1985). Immunoreactive fibers are mainly located in the central gray matter (Chronwall et al, 1985; see Gray and Morley, 1986 for review). In the monkey brain, numerous NPY-terminals have been visualized in the interpeduncular nucleus (Smith et al, 1985). With the exception of the locus coeruleus, the lateral parabrachial white matter, most regions of the mesencephalon are poorly innervated (Adrian et al, 1983; Chronwall et al, 1985; Smith et al, 1985). In rats, a relatively high number of NPY cell bodies are located in the dorsal part of the locus coeruleus. However, in monkey, no positive cell bodies can be observed in this region (Smith and Parent, 1986). The presence of a small 
cluster of NPY-perikarya surrounding the dorsal nucleus of the tegmentum should also be mentioned. In the medulla oblongata, NPY-cell bodies are located in the whole rostro-caudal region of the nucleus of the solitary tract (Harfstrand $e t a l$, $1987 \mathrm{a}, \mathrm{b}$ ) and in the ventro-lateral medulla (Carter $e t$ al, 1985). The nucleus of the tractus solitarius, the dorsal vagal nucleus, the raphe and the giganto-cellular nucleus are moderately innervated by NPY-nerve fibers.

NPY-immunoreactive fibers are located in the entire medulla (Gibson et al, 1984). A comparative study conducted on 5 different species has shown that immunoreactivity is particularly dense in the lumbosacral segment of the medulla, around the central canal, and in the dorsal horn (Gibson et al, 1984). In the cat medulla, NPY-perikarya have been detected in the dorsal horn (Gibson et al, 1984; Krukoff, 1987), suggesting that at least part of the innervation of the medulla may have an intrinsic origin. Similar results have also been reported in non-mammalian vertebrates (Danger et al, 1985). Taken together, these results suggest that NPY is synthesized, and stored in numerous brain areas. The presence of messenger RNA in the rat hypothalamus has been demonstrated using in vitro translation (Ivell $e t a l, 1984)$. Recently, in situ hybridization studies have established that NPY is actually produced in brain neurons (Terenghi et al, 1987; Chan-Palay, 1988).

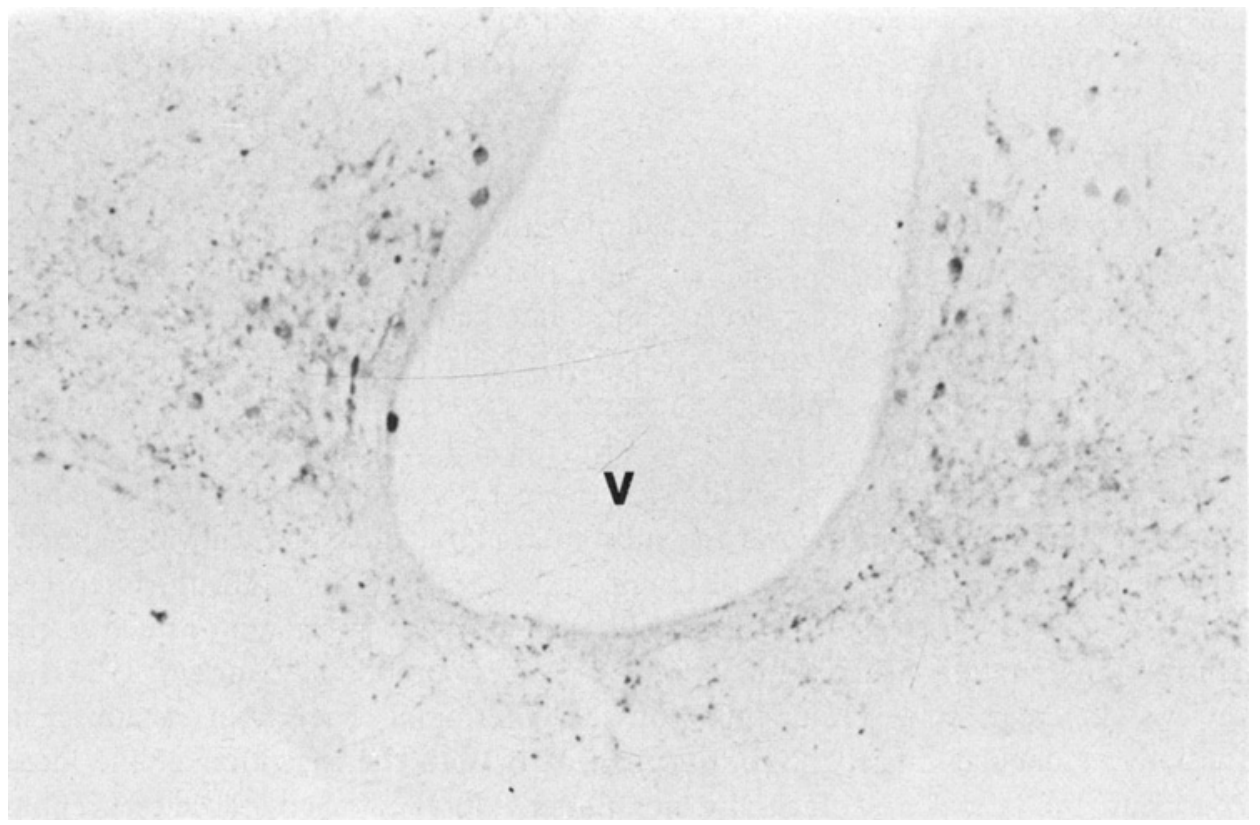

Fig 3. Coronal section through the medial basal hypothalamus of the rat. Numerous cell bodies are labelled by the NPY antiserum, using the peroxidase-antiperoxidase technique in the arcuate nucleus. A dense network of immunopositive fibers can also be observed in the internal zone of the median eminence. V, ventricule; $(\times 200)$. 


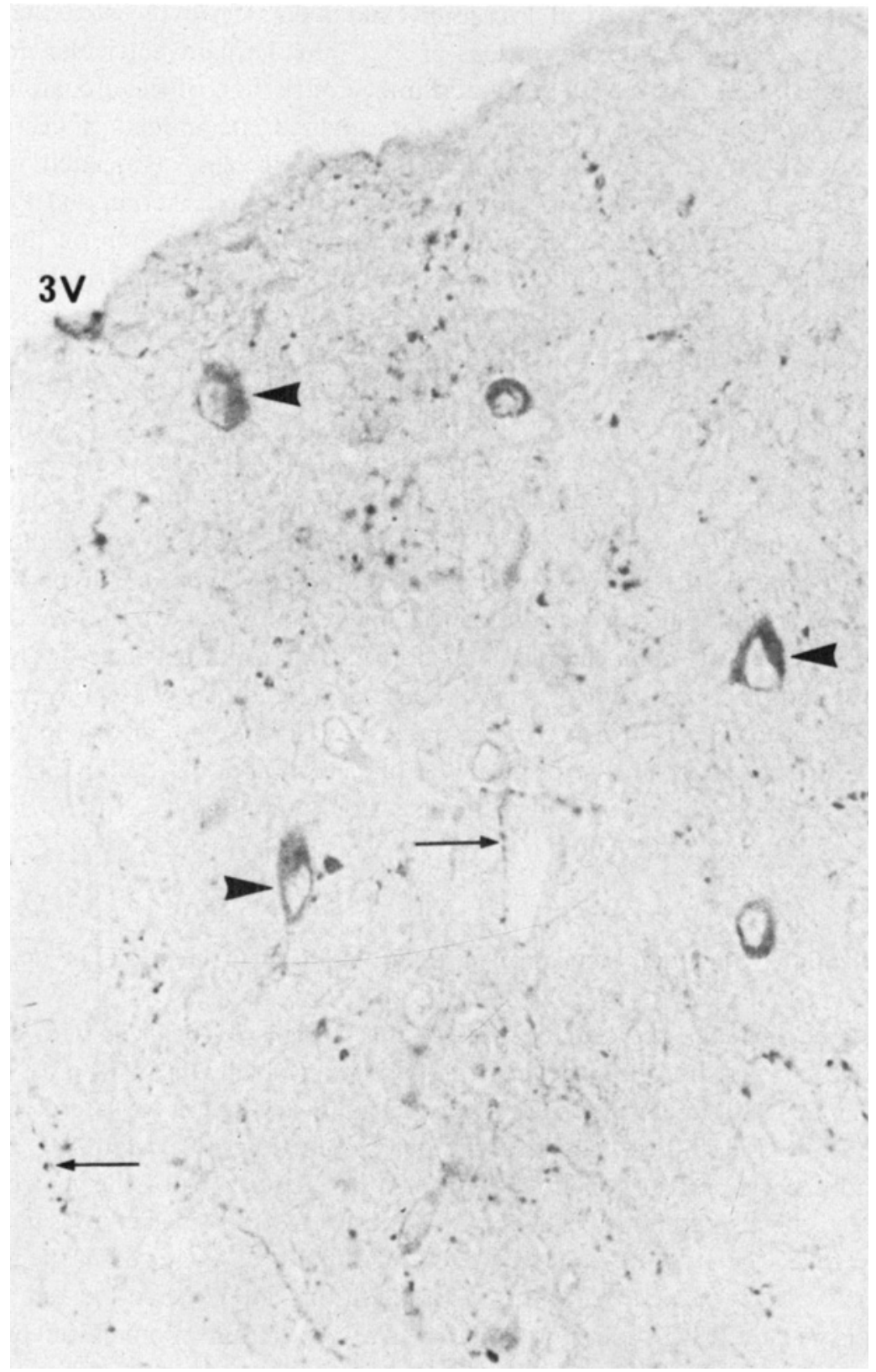

Fig 4. Section through the human basal hypothalamus. Several cell bodies are labelled by the NPY antiserum, in the infundibular nucleus (arrowheads). Immunoreactive beaded fibers are also immunostained (arrows). 3V, third ventricle; $(\times 450)$. 
The widespread distribution of NPY neuronal systems makes it difficult to determine precisely the organization of the NPY neuronal pathways in the brain. However, a few studies have revealed that NPY may send projections over a long distance in the brain. Electrical lesioning experiments have revealed that NPY perikarya located in the arcuate nucleus project into the paraventricular and dorsal hypothalamus (Bai et al, 1985). In addition, destruction of the arcuate nucleus using post-natal treatment with monosodium-L-glutamate induces a decrease in the density of NPY fibers in the paraventricular nucleus, associated with an increase of the number of NPY perikarya in this nucleus (Kerkérian and Pelletier, 1986). Thus the arcuate nucleus may exert a tonic inhibitory action on the NPYcontaining neurons located in the paraventricular nucleus. Electrical lesioning experiments have also shown that the NPY-nerve fibers located in the suprachiasmatic nucleus originate in part from the lateral geniculate nucleus (Harrington $e t$ $a l, 1985)$. Depletion of NPY-fibers of the suprachiasmatic nucleus has also been observed following transection of the stria terminalis (Allen et al, 1984a). NPYneurons located in the amygdala complex may be the origin of the fibers located in the suprachiasmatic area. Retrograde labelling experiments indicate that the NPY-innervation of the dorsal vagal complex originates partly from the NPYperikarya located in the parvo-cellular region of the periventricular hypothalamus (Gray et al, 1986). Finally, retrograde tracing techniques have shown that the innervation of the rat hippocampus is of both intrinsic and extrinsic origins. The intrinsic system is constituted of cortical neurons located in the deep layers of the perirhinal area of the piriform cortex. The extrinsic innervation originates from cortical neurons located in the deep of the perirhinal area of the piriform cortex from the rostro-caudal endopiriform nucleus, the lateral amygdala and the locus coeruleus (Köhler et al, 1986b).

\section{Co-localization with other neurotransmitters and/or neuropeptides in the brain}

Immunohistochemical studies have revealed that NPY is co-localized with biogenic amines in various areas of the central nervous system. In rats, most of the noradernergic cells and some adrenergic neurons of the ventro-lateral medulla oblongata are also stained using an NPY-antiserum (Everitt $e t$ al, 1984). Numerous noradrenergic perikarya and a few dopaminergic neurons of the ventromedial locus coeruleus also contain NPY-like immunoreactivity (Sawchenko et al, 1985). In man, Hökfelt et al, (1983a) have shown that NPY is co-localized in the medulla oblongata with tyrosine hydroxylase. In addition, NPY is co-located with $\gamma$ aminobutyric acid (GABA) in pyramidal cells of the cat and monkey cerebral cortex (Hendry et al, 1984b).

Co-localization of NPY with other neuropeptides has also been investigated by means of immunohistochemistry (table I). NPY is present in somatostatinergic neurons of the cortex (Vincent et al, 1982; Chronwall et al, 1984), hippocampus, 
where the co-localization rate is particularly high (Köhler et al, 1987a; ChanPalay, 1987), the olfactory bulb (Beal et al, 1986), pericentral nucleus of the colliculus and the periaqueductal gray layer (DeQuidt and Emson, 1986). NPY has also been detected in perikarya containing the molluscan cardio-excitatory peptide (FMRF-amide) in the medulla oblongata, the hypothalamus and in the medulla (Hökfelt et al, 1983b; see Chronwall, 1985 for a review; Sasek and Elde, 1985). NPY is co-localized with galanin in the locus coeruleus (Holets et al, 1985), with VIP in neurons of the cranial parasympathetic ganglia (Leblanc et al, 1987) and with CCK in perikarya of the nucleus of the solitary tract (Harfstrand et al, 1987a). Recently, Ciofi et al, (1988) have shown that in rats NPY is present in GRF-containing neurons of the hypothalamus.

The structural relationship between NPY and other neuronal systems has been investigated using various approaches. In rats, unilateral and selective lesion of the nigrostriatal dopaminergic neurons induces an increase in the number and staining intensity of the ipsilateral striatum (Kerkérian et al, 1986). These results suggest that the NPY-neuronal system of the rat striatum is under the inhibitory control of dopaminergic afferents of the nigrostriatal pathway. Ultrastructural studies combining immunohistochemistry and autoradiography have revealed axoaxonic contacts between NPY-ergic and serotoninergic fibers (Guy et al, 1988b). In the rat accumbens nucleus, synaptic contacts have been observed between NPY-ergic dendrites and glutamic acid decarboxylase (GAD) immunoreactive terminals (Massari et al, 1984). Axo-somatic synapses between NPY-fibers and

Table 1. Overview of co-localization of NPY with other putative neurotransmitters in the brain.

\begin{tabular}{|c|c|c|}
\hline Substance & Localization & References \\
\hline Catecholamines & $\begin{array}{l}\text { Noradrenergic and adrenergic cell groups of } \\
\text { the medulla oblongata, noradrenergic cells } \\
\text { of the locus coeruleus and medulla oblon- } \\
\text { gata }\end{array}$ & $\begin{array}{l}\text { Everitt et al, } 1984 \\
\text { Hökfelt } \text { et al, 1983a } \\
\text { Sawchenko et al, } 1985\end{array}$ \\
\hline Somatostatin & $\begin{array}{l}\text { Cortex, striatum, hippocampus, olfactory } \\
\text { bulb, pericentral nucleus of the inferior col- } \\
\text { liculus, periaqueductal gray }\end{array}$ & $\begin{array}{l}\text { Chronwall et al, } 1984 \\
\text { Beal et al, } 1986 \\
\text { Vincent et al, } 1982 \\
\text { Köhler et al, } 1987 \\
\text { Chan-Palay, } 1987\end{array}$ \\
\hline GABA & Pyramidal cells of the cerebral cortex & Hendry et al, 1984b \\
\hline Galanin & Locus coeruleus & Holets et al, 1985 \\
\hline GRF & Arcuate nucleus & Ciofi et al, 1988 \\
\hline FMRF-amide & $\begin{array}{l}\text { Hypothalamus, medulla oblongata, } \\
\text { spinal cord }\end{array}$ & $\begin{array}{l}\text { Hökfelt et al, 1983b } \\
\text { Chronwall, } 1985 \\
\text { Sasek and Elde, } 1985\end{array}$ \\
\hline VIP & Parasympathetic cranial ganglion & Leblanc et al, 1987 \\
\hline
\end{tabular}


corticotropin-releasing factor (CRF) have recently been demonstrated in the parvocellular region of the periventricular nucleus of the rat hypothalamus (Liposits et al, 1988).

\section{Ontogeny of NPY in the brain}

A few studies have been conducted in order to determine the ontogeny of NPY in the brain of mammals. In rats NPY is present as early as day 14 of intra-uterine life (E14) in the diencephalon, but appears only at E19 in the cerebral cortex. NPY-concentrations increase rapidly following birth (Allen et al, 1984b). The embryonic development of NPY-neuronal systems is homologous to that of catecholaminergic neurons (Allen et al, 1984b). In fact, NPY and tyrosine hydroxylase are co-localized in neurons of the medulla oblongata from E17 (Foster et al, 1984). According to these authors, NPY-immunoreactivity appears at E13 but development of NPY neurons is independent from that of tyrosine hydroxylaseimmunopositive neurons. The results of this study indicate that NPY and tyrosine hydroxylase are not systematically associated and that the factors which regulate the synthesis of these products are not identical.

\section{Receptors}

The presence of receptors to NPY in the rat brain was initially reported by Unden et al, (1984). The highest concentration of NPY binding sites has been detected in membrane preparations from rat cerebral cortex, hypothalamus, hippocampus (Unden et al, 1984), and in the vasomotor region of the medulla oblongata (Nakajima et al, 1986). NPY binding on membrane receptors depends on the presence of calcium (Goldstein et $a l, 1986)$ and is inhibited by magnesium (Unden and Bartfai, 1984). Using the C-terminal fragment NPY ${ }^{13-36}$ (Sheikh et al, 1989) have recently identified two subtypes of neuropeptide $Y$ (named $Y_{1}$ and $Y_{2}$ ), which differ in affinity and specificity. The $Y_{1}$ subtype binds NPY with a dissociation constant in the nanomolar range, but does not bind NPY ${ }^{13-56}$. The $Y_{2}$ subtype exhibits a high affinity for both NPY and NPY ${ }^{13-36}$. The NPY receptor is sensitive to proteolytic enzyme treatment and to reducing agents (Unden and Bartfai, 1984). Table II gives the relative quantities of ${ }^{125} \mathrm{I}$-labeled peptide YY $\left({ }^{125} \mathrm{I}\right.$ labeled PYY) and ${ }^{125}$ I-labeled Bolton-Hunter neuropeptide Y ( ${ }^{125}$ I-labeled BHNPY) binding sites in the hypothalamus and pituitary gland of rat as determined by in vitro receptor autoradiography (Martel et al, 1989). The labeling of various hypothalamic nuclei and the pituitary gland is generally stronger when using ${ }^{125}$ Ilabeled PYY. The 2 ligands used here most likely interact with a similar population of receptor sites in the CNS (Walker and Miller, 1988; Martel et al, 1989). However, PYY differentiates better than NPY 2 of the affinity states (high and 
Table II. Comparative distribution of [125I]peptide YY and ${ }^{125}$-labeled Bolton-Hunter neuropeptide $\mathrm{Y}$ receptor sites in hypothalamic nuclei and pituitary gland in the rat. Relative densities in lateral septum frontal cortex and hippocampus are given for comparison. $+++:$ high density; $++:$ moderate density; + : low density; - : very low density.

\begin{tabular}{|c|c|c|}
\hline Area & I $\left.^{125} I\right] P Y Y$ Relative density & 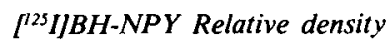 \\
\hline \multicolumn{3}{|l|}{ Hypothalamus } \\
\hline Paraventricular nucleus & ++ & + \\
\hline \multicolumn{3}{|l|}{ Preoptic area } \\
\hline (medial and lateral) & ++ & + \\
\hline Medial preoptic nucleus & + & + \\
\hline Lateral hypothalamic area & ++ & + \\
\hline Septohypothalamic nucleus & ++ & + \\
\hline Suprachiasmatic nucleus & + & ++ \\
\hline Lateroanterior nucleus & $+t$ & + \\
\hline Ventromedial nucleus & ++ & + \\
\hline Supraoptic nucleus & ++ & + \\
\hline \multicolumn{3}{|l|}{ Pituitary gland } \\
\hline Anterior lobe & - & - \\
\hline Intermediate lobe & - & - \\
\hline Neural lobe & ++ & - \\
\hline \multicolumn{3}{|l|}{ Other areas } \\
\hline Lateral septum & +++ & +++ \\
\hline Frontal cortex (layers I-II) & ++ & ++ \\
\hline Hippocampus (stratum radiatum) & +++ & ++ \\
\hline
\end{tabular}

moderate) of the receptors (Walker and Miller, 1988). Accordingly, with the concentration of radioligands used in the present study (35 pM), ${ }^{125}$ I-labeled PYY should label a greater proportion of the high affinity states of the receptors. It is also important to point out that PYY-like immunoreactivity has been detected in the hypothalamus, brainstem and spinal cord of the rat (Ekman et al, 1986). It is therefore possible that specific ${ }^{125}$ I-labeled PYY receptors demonstrating low affinity for ${ }^{125}$ I-labeled BH-NPY may exist in these brain areas. It should be noted, however, that neither $Y_{1}$ nor $Y_{2}$ subtype of binding site distinguish between NPY and PYY (Sheikh et al, 1989).

In comparison to other regions such as the hippocampus and the cortex, the amounts of ${ }^{125}$ I-labeled PYY binding sites in the hypothalamus and pituitary gland vary from low to moderate (table II). On the other hand, comparatively low levels of ${ }^{125}$ I-labeled BH-NPY are seen in most hypothalamic nuclei and the pituitary gland (table II). The moderate levels of ${ }^{125}$ I-labeled PYY binding observed in the paraventricular hypothalamic nucleus is of particular interest in regard to the stimulatory effect of discrete injection in this nucleus of NPY or PYY on food intake (Stanley et al, 1985b). It has also been shown that PYY is more potent than NPY in eliciting this behavior, supporting our finding of higherlevels of ${ }^{125}$ I-labeled PYY than ${ }^{125}$ I-labeled BH-NPY sites in the paraventricular 
nucleus. The existence of moderate concentrations of ${ }^{125}$ I-labeled PYY sites in the preoptic area is consonant with the view that NPY plays a pivotal role in the regulation of LH secretion (see below).

The moderate quantities of ${ }^{125}$ I-labeled PYY binding observed in the neural lobe of the pituitary gland may suggest a role for NPY and/or PYY on the release of neurohypophysial hormones such as vasopressin and/or oxytocin. It has already been shown that injection of NPY in the supraoptic nucleus, which contains a moderate density of ${ }^{125}$ I-labeled PYY sites, induced the secretion of vasopressin (Willoughby and Blessing, 1987). The presence of ${ }^{125}$ I-labeled PYY sites in the neural lobe of the pituitary gland may also suggest possible effect of this peptide family directly at the level of vasopressin nerve terminals. Finally, the absence of significant labeling with either ${ }^{125}$ I-labeled PYY or ${ }^{125}$ I-labeled BHNPY in the anterior pituitary of male rats is in agreement with the lack of direct effect of these peptides on the release of pituitary hormones (see below). However, a sex difference in the expression of these receptors cannot be excluded, since a direct effect of NPY on the release of anterior pituitary hormones has been reported in female rats (McDonald et al, 1985a). The absence of ${ }^{125} \mathrm{I}$-labeled $\mathrm{BH}-$ NPY and/or ${ }^{125}$ I-labeled PYY binding sites in certain areas may also reflect species differences in the distribution of these sites. Such a situation may occur in the intermediate lobe of the pituitary, since NPY inhibits MSH release in the frog (Danger et al, 1986) while it does not affect MSH secretion in the rat (Kraicer et $a l, 1988)$. It should also be pointed out that some areas may contain ${ }^{125}$ I-labeled BH-NPY and/or ${ }^{125}$ I-labeled PYY receptor sites which cannot be detected with the relatively low concentration of radioligands used in this study. Finally, the presence of ${ }^{125}$ I-labeled PYY receptor sites in other hypothalamic nuclei such as the septo-hypothalamic, latero-anterior and ventromedial nuclei deserves further investigation.

\section{Behavioral actions of NPY}

The widespread distribution of NPY in the brain suggests that the peptide exerts various behavioral actions. Clark et al, (1984) initially showed that injection of NPY in the third ventricle increased feeding behavior in rats. This powerful orexigenic action of NPY was subsequently confirmed by Levine and Morley (1984). Stanley and Leibowitz (1984) and Clark et al, (1985). In addition, these groups have observed that stimulation of food intake also occurs after direct injection of NPY in the paraventricular nucleus of the hypothalamus. NPY induces feeding in other species such as mouse (Morley et al, 1987), squirrel (Nizielski et al, 1985), and swine (Parott $e t a l, 1986$ ). The action of NPY is not inhibited by $\alpha$-adrenergic antagonists (Stanley and Leibowitz, 1984; Levine and Morley, 1984). While norepinephrine only acts on food intake, NPY also induces drinking behavior (see Morley, 1987, for a review). It thus appears that the orexigenic effect does not 
depend on noradrenergic neurotransmission. The distribution of NPY neurons and NPY receptors suggests that the peptide may play a physiological role in the control of feeding. As a matter of fact, NPY is located in various brain areas known to be involved in the control of appetite such as the paraventricular, the dorsomedial and the preoptic nuclei, the ventral tegmental area, the amygdala, the locus coeruleus and the nucleus of the solitary tract. It should be mentioned that the nucleus of the solitary tract is particularly rich in NPY binding sites (Harfstrand et al, 1986; Nakajima et al, 1986; Martel et al, 1989). This population of NPY binding sites is of importance, since stimulation of feeding behavior has also been observed following injection in the fourth ventricle (Steinman et al, 1987). Several attempts have been to determine the precise site of action of NPY. Injection of NPY in the paraventricular nucleus and in the ventromedial nucleus of the hypothalamus stimulates both drinking and feeding, whereas only increased drinking is observed following injection in the lateral hypothalamus (Stanley and Leibowitz, 1984). The lesion of the paraventricular and ventromedial nuclei does not prevent the orexigenic action of the peptide. Stimulation of feeding is also observed following micro-injection in the medial preoptic area (Stanley et al, 1985a). However, no behavioral modification is observed when NPY is administered in the amygdala or thalamus (see Morley, 1987, for a review). Finally, it has been shown that NPY injections are capable of reversing the loss of body weight induced by lesions of the lateral hypothalamus (see Morley, 1987, for a review). All these data support a role of NPY in the dorsal medial, the anterior hypothalamus and the ventral tegmental area on appetite and body weight (table III).

NPY also acts on sexual behavior. In rats, intracerebroventricular injection of NPY inhibits the receptivity of females to males: a 50\% inhibition of lordosis was measured after icv injection of $0.05 \mathrm{~g}$ of NPY. For higher doses, rejection behavior increases (Clark et al, 1985). Whether this action can be accounted for by the inhibitory affect of NPY on LH secretion remains unknown.

\section{Miscellaneous actions of NPY at the brain level}

NPY appears to be a peptide of prime importance in the regulation of cerebral blood flow (table III). In addition to its distribution in central arteries and in the main blood vessels of the circle of Willis, NPY has been shown to induce a powerful, long-lasting diminution of cortical blood flow (see Edvinsson, 1985, for a review). NPY causes a shift of circadian rhythms in hamster (Albers and Ferris, 1984) and modulates biosynthesis of melatonin by increasing the activity of serotonin acetyltransferase (Reuss and Schröder, 1987). NPY also affects cerebral electrical activity (Fuxe et al, 1983; Zini et al, 1984). Intracerebral injection of NPY reduces cardiac and respiratory frequencies (Fuxe et al, 1983; Harfstrand, 1986) and arterial pressure (Fuxe et al, 1983; 1986; Harfstrand, 1986). Central 
Table III. Physiological effects of central administration of NPY.

\begin{tabular}{ll}
\hline Pharmacological action & References \\
\hline Modification of circadian rhythms & Albers and Ferris, 1984 \\
Stimulation of melatonin biosynthesis & Reuss and Schröder, 1987 \\
Stimulation of feeding and drinking behaviour & Clark et al, 1984 \\
& Morley, 1987 \\
& Morley et al, 1987 \\
& Stanley and Leibowitz, 1984 \\
Modification of arterial pressure and cardiac rhythms & Stanley et al, 1985a \\
& Fuxe et al, 1983 \\
Modification of respiratory rhythms & Harfstrand, 1986 \\
& Fuxe et al, 1983 \\
Modification of brain electrical activity & Harfstrand, 1986 \\
Hypothermia & Fuxe et al, 1983 \\
Stimulation of insulin secretion & Zini et al, 1984 \\
& Morioka et al, 1984 \\
Inhibition of libido & Moltz and Donald, 1985 \\
Modulation (mainly inhibition) of LH secretion & Kuenzel, 1988 \\
\hline
\end{tabular}

administration of NPY causes hypothermia in dog (Morioka et al, 1984) and stimulates insulin secretion (Moitz and McDonald, 1985; Kuenzel, 1988).

\section{Effect of NPY on anterior pituitary hormone secretion}

Intravenous administration of NPY in castrated male rats induces a marked inhibition of LH secretion (Kerkérian et al, 1985) without affecting the release of other pituitary hormones. These observations have been confirmed in ovariectomized female rats (Kalra and Crowley, 1984; McDonald et al, 1985a, b). These data, together with the location of NPY-containing neurons in the arcuate nucleus (Chronwall et al, 1984; Pelletier et al, 1984b) at first suggested that NPY could act as a neurohormone which selectively inhibits pituitary LH secretion. This hypothesis was apparently supported by the observation that intravenous injection of NPY antiserum to castrated female rats causes a robust stimulation of LH secretion (Guy et al, 1988a). However, several lines of evidence indicated that NPY does not exert a direct effect on pituitary gonadotrophs. In vitro studies showed that NPY has no effect on LH and FSH release from pituitary cells in primary culture, obtained from intact female rats (Kerkérian et al, 1985). Synthetic NPY has no effect either ou hemi-pituitaries from intact male or ovariectomized female rats (Rodriguez-Sierra et al, 1987). However, should it be mentioned that 2 groups have reported a stimulatory effect of NPY on LH release 
from perifused gonadotrophs of ovariectomized rats (McDonald et al, 1985a; Crowley et $a l, 1987)$. They also showed that NPY potentiates the effect of LHRH on LH secretion from hemi-pituitaries. However, NPY appears to be totally devoid of effect on LHRH-evoked LH release from anterior pituitary cells in primary culture (Kerkérian et al, 1985). Moreover, autoradiographic studies using either ${ }^{125}$ I-labeled PYY or ${ }^{125}$ I-labeled BH-NPY show that the anterior lobe of the rat pituitary does not contain NPY binding sites (table II).

In the absence of any direct effect of NPY on anterior pituitary cells it was reasonable to postulate that NPY may exert its action at the level of the central nervous system. This hypothesis is strongly supported by experimental data. Intracerebroventricular injection of NPY stimulates $\mathrm{LH}$ release in steroid-primed ovariectomized rats but causes a significant inhibition of $\mathrm{LH}$ secretion in castrated male and female rats (Kalra and Crowley, 1984; Kerkérian et al, 1985). Since the central effect of NPY is mimicked by intravenous injection of this peptide (Kerkérian et al, 1985), it was hypothesized that NPY may affect LHRH release in 2 diencephalic regions which lack the blood-brain barrier: i), the area of the organum vasculosum of the lamina terminalis (OVLT) which contains both LHRH neurons (Pelletier, 1980) and NPY nerve fibers and exhibits a moderate density of NPY binding sites (table II); ii), the median eminence which contains LHRH and NPY nerve terminals. Double-staining immunohistochemical techniques have shown the presence of NPY fibers contacting LHRH cell bodies in the OVLT region (figure 5). In contrast, in the median eminence, the LHRH axon terminals are found in high concentrations in the external zone while NPY fibers are only observed in the internal zone, and thus contacts do not occur between the 2 types of fibers. On the basis of these morphological studies, it appears that NPY neurons may regulate LH secretion through a direct inhibitory effect on LHRH neurons of the preoptic area. In agreement with this hypothesis, Khorram et al (1987) using the push-pull technique have shown that NPY modulates the release of LHRH in the rabbit hypothalamus. In contrast, Crowley and Kalra (1987), using in vitro incubation of medial basal hypothalamus, observed a stimulatory effect of NPY on LHRH release. It is also worth mentioning that in cold blooded vertebrates NPY regulates gonadotropin release through presynaptic control of LHRH neurons (Danger et al, submitted).

Pharmacological studies have shown that treatment of rats with $\alpha$-methylparatyrosine ( $\alpha$-MPT) did not affect the inhibitory action of NPY on LH secretion (Guy et al, 1988a). In rats treated with 5,7-dihydroxytryptamine (5,7-DHT), intraventricular injection of NPY causes a marked increase of LH release (Guy et al, 1988a). These data indicate that the effect of NPY on LH secretion is not mediated by noradrenergic neurons but suggest that NPY may act presynaptically on serotonin neurons. Several studies have shown that serotonin causes an inhibition of LH secretion (Schneider and McCann, 1979; Kordon and Glowinsky, 1972). We thus propose that NPY may have a physiological effect on LH secretion through 2 distinct pathways: i), a direct effect on the LHRH neuronal sys- 

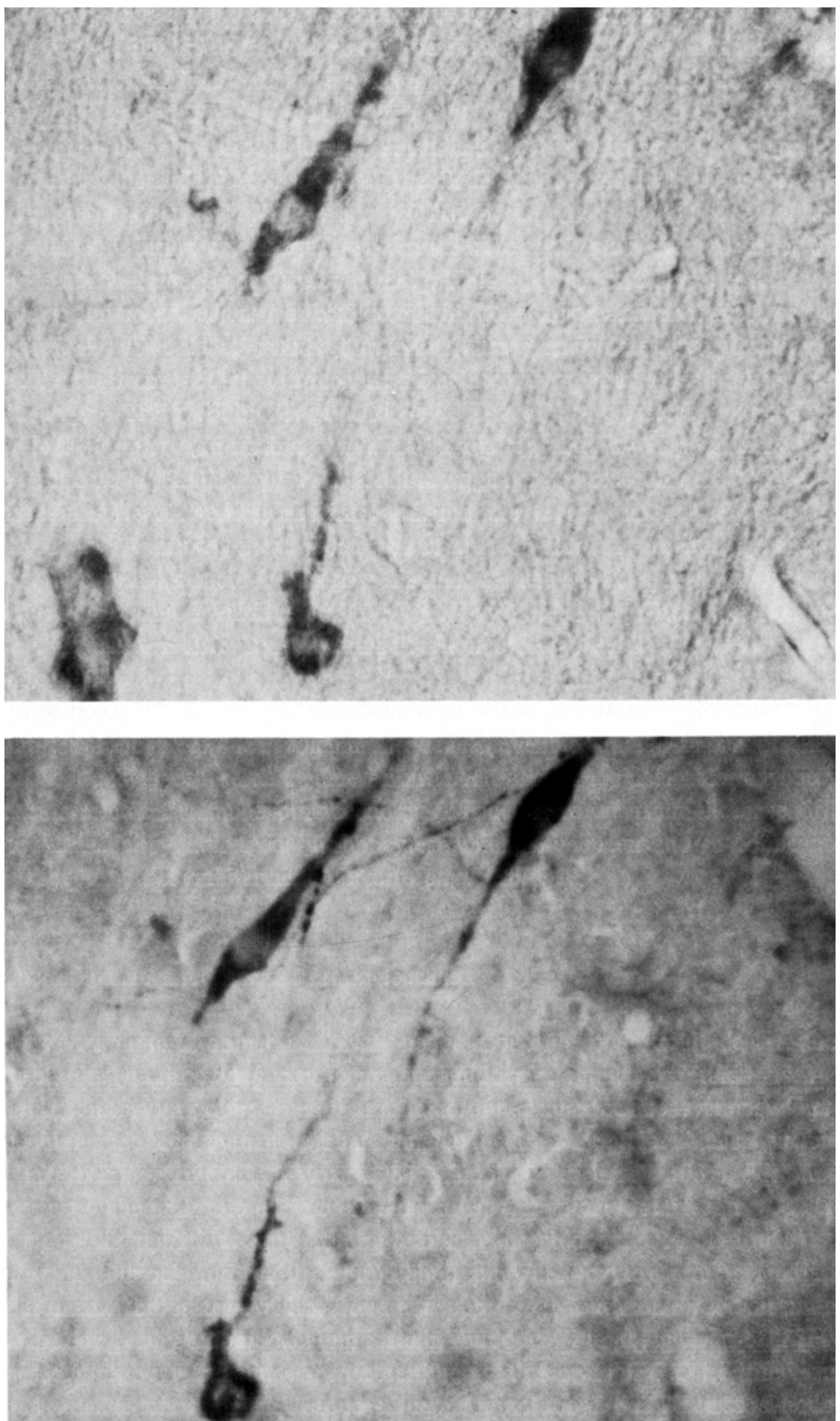
tem; ii), a stimulatory effect on serotoninergic fibers which, in turn, inhibit LHRH release (fig 6 ).

It should be noted, however, that a direct effect of NPY on pituitary gonadotrophs cannot be exclused. Recent experiments indicate that NPY stimulates LH release from pituitary cells of female rats (Chabot et al, 1988). Although NPY immunoreactive axon terminals are not observed in the external zone of the median eminence (Allen et al, 1983), high concentrations of NPY are found in the hypothalamo-pituitary portal blood (McDonald et al, 1987). Several studies support the notion that steroid hormones play a crucial role in the neuroendocrine functions of NPY (Breton et al, 1989). Administration of ovarian steroids elevates the concentrations of NPY in the arcuate nucleus of the rat (Crowley et al, 1985). NPY inhibits LHRH release by hypothalamic neurons in normal female rabbits, while in ovariectomized animals NPY stimulates LHRH release (Khorram et al, 1987). Similarly, Kalra and Crowley (1984) observed opposite effects of NPY on $\mathrm{LH}$ release, depending on whether animals were ovariectomized or not. Recent evidence also indicates that castration of male rats induces a significant decrease of NPY concentrations in the median eminence, arcuate nucleus and ventromedial nucleus (Sahu et $a l, 1987$ ) and that testosterone treatment of gonadectomized male rats restored NPY concentrations in these hypothalamic areas (Sahu et al, 1989).

Possible action of NPY on secretion of other pituitary hormones has been examined (table IV). McDonald et al (1985a) have shown that NPY stimulates growth hormone $(\mathrm{GH})$ secretion both in vivo and in vitro. However, the concentrations of NPY required to influence GH release are 100 -fold higher than those used to inhibit LH release. Chabot et al, (1988) have also observed that NPY stimulates GH and prolactin (PRL) secretion by cultured pituitary cells. In contrast, NPY inhibits $\mathrm{GH}$ release from human somatotroph tumor cells (Adams et al, 1987). Recent studies indicate that injection of NPY in the paraventricular nucleus of conscious rats stimulates adrenocorticotropin (ACTH) and corticosterone release (Haas and George, 1987; Wahlestedt et al, 1987). This effect of NPY likely occurs at the hypothalamic level, since intravenous injection of NPY does not modify circulating ACTH levels (Kerkérian et al, 1985).

Fig 5. Microphotograph of a brain section through the rat preoptic area demonstrating that NPY endings are in apposition to LHRH cell bodies. The section has been labelled by the peroxidaseantiperoxidase method using a double immunostaining technique. In the first step (top) staining for LHRH was performed and the reaction photographed. In the second step (bottom), the same section was stained for NPY. NPY fibers not detected in the first step appear in close apposition to LHRH cell bodies; ( $\times 560$ ). (From Guy J et al, Regul Peptides 209-216, 1988; with permission). 


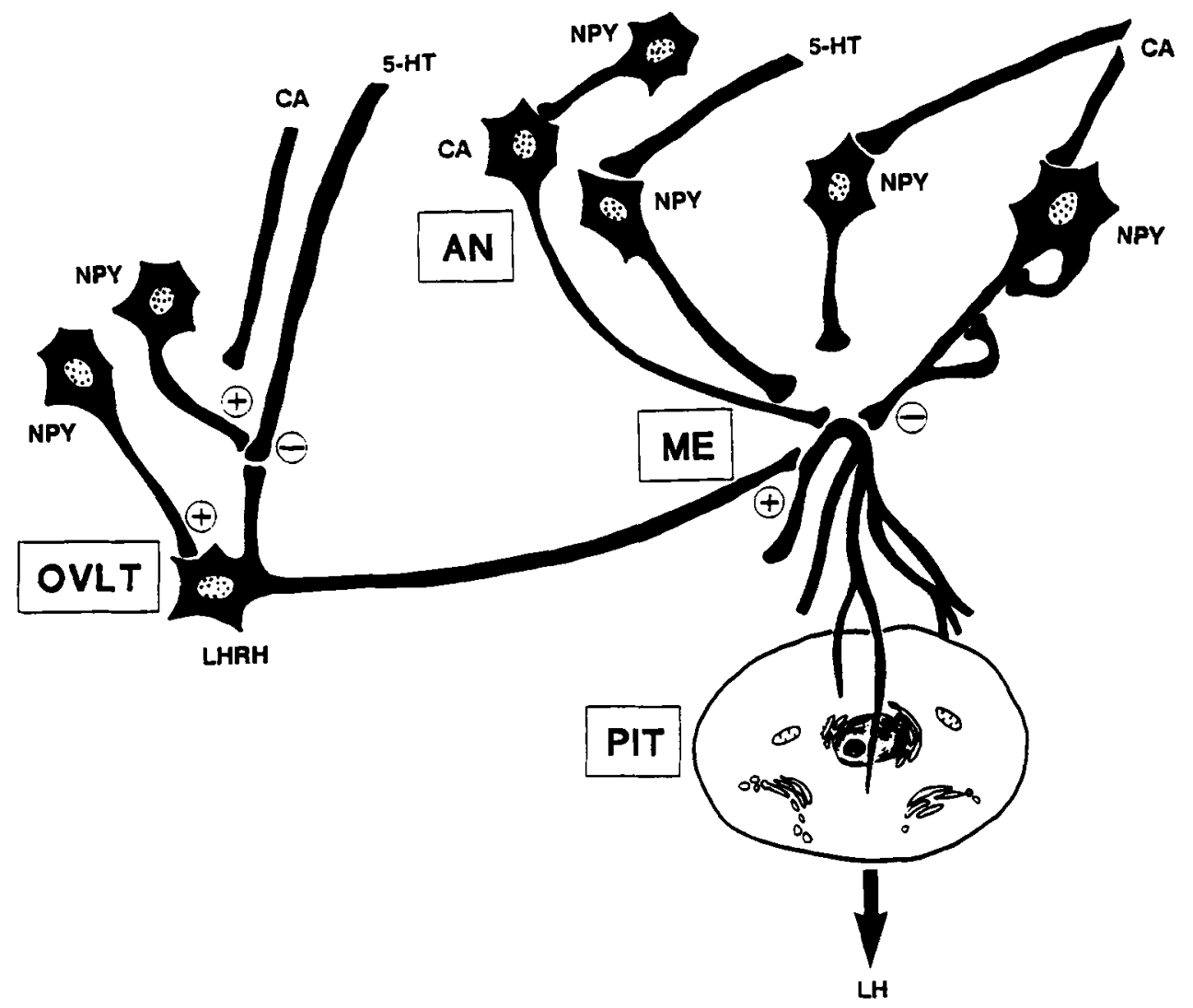

Fig 6. A diagram depicting the various neuronal systems involved in the mechanism of action of NPY on LH secretion. The--and + symbols indicate inhibitory and stimulatory effects respectively. AN, arcuate nucleus; ME, median eminence; OVLT, organum vasculosum lamina terminalis; PIT, pituitary.

\section{Effect of NPY on posterior pituitary hormone secretion}

Anatomical studies indicate that NPY-immunoreactive nerve terminals are found in the close vicinity of vasopressinergic neurons (Willoughby and Blessing, 1987). Injection of NPY into the supraoptic nucleus of conscious rats induces an increase in plasma vasopressin concentrations (Willoughby and Blessing, 1987). Electrophysiological studies have shown that NPY stimulates the activity of vasopressinergic neurons (Dray et al, 1986). In addition, NPY may exert an effect on vasopressin release in the neural lobe, as suggested by the presence of NPY receptors in the pars nervosa of rat (table II) and man (data not shown).

The possible role of NPY in the control of pars intermedia secretion has been investigated in non-mammalian vertebrates. Morphological studies indicate that in all vertebrate studies, NPY-containing neurons are widely distributed throughout 
Table IV. Effect of NPY on gonadotropin and LHRH secretion.

+ , stimulation; - , inhibition; 0 , no effect; ?, not determined.

\begin{tabular}{|c|c|c|c|}
\hline Animal & Technique & Pharmacological action & References \\
\hline \multicolumn{4}{|c|}{ in vivo } \\
\hline Male rat & Sub-cutaneous injection & LH + ; FSH 0 & $\begin{array}{l}\text { Rodriguez-Sierra } \\
\text { et al, } 1987\end{array}$ \\
\hline Castrated male rat & ICV or IV injection & LH-; FSH 0 & Kerkérian et al, 1985 \\
\hline Castrated female rat & ICV injection & LH-; FSH 0 & $\begin{array}{l}\text { McDonald et al, } \\
\text { 1985a, b } \\
\text { Kalra and Crowley, } \\
1984\end{array}$ \\
\hline \multicolumn{4}{|c|}{ 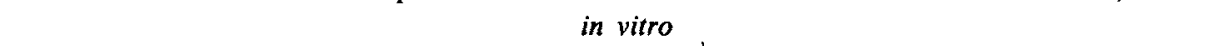 } \\
\hline Male rat & Hemi pituitaries & LH $0 ;$ FSH 0 & $\begin{array}{l}\text { Rodriguez-Sierra } \\
\text { et al, } 1987\end{array}$ \\
\hline Female rat & Cultured pituitary cells & LH 0 ; FSH 0 & Kerkérian et al, 1985 \\
\hline Castrated female rat & Hemi pituitaries & LH 0; FSH ? & Crowley et al, 1987 \\
\hline & $\begin{array}{l}\text { Cultured pituitary cells } \\
\text { and perifused cells }\end{array}$ & $\mathrm{LH}+;$ FSH 0 & McDonald et al, 1985a \\
\hline
\end{tabular}

the brain. In the amphibian hypothalamus, 3 distinct groups of NPY-ergic neurons have been visualized by immunocytochemistry in the preoptic nucleus and in the dorsal and ventral infundibular nuclei (Danger et al, 1985; Perroteau et al, 1988). These neurons contain both NPY- and C-PON-like immunoreactivity (Caillez et al, 1987a, b); suggesting that the structure of the pro-peptide has been highly preserved during evolution. In support of this assumption, NPY-like peptides have been localized and characterized in several non-vertebrate species (Charmantier-Daures et al, 1987; Rémy et al, 1988; Schoofs et al, 1988). In fish (Vallarino et al, 1988; Pontet et al, 1989) and in anurans (Danger et al, 1986; Caillez et al, 1987a, b; Verburg van Kemenade et al, 1987a), numerous fibers originating from the hypothalamus terminate in the intermediate lobe of the pituitary (figure 7). In the goldfish, NPY fibers also innervate gonadotrophs and somatotrophs of the adenohypophysis (Pontet et al, 1989). Several immunocytochemical studies have been conducted at the electron microscopic level to determine the subcellular localization of NPY (Danger et al, 1986; Pontet et al, 1989). In both fish and amphibians, NPY immunoreactive material is sequestered in small $(80-100 \mathrm{~nm})$ dense core vesicles. These electron microscopic studies also revealed that NPY-containing axon terminals contact melanotrophs of the pars intermedia (figure 8). It is worth mentioning that in urodeles NPY innervation is lacking in the intermediate lobe of the pituitary (Perroteau et al, 1988). These anatomical data represent the neuroanatomical substrate for possible neuroendocrine regulation of the pituitary melanotrophs by NPY. 


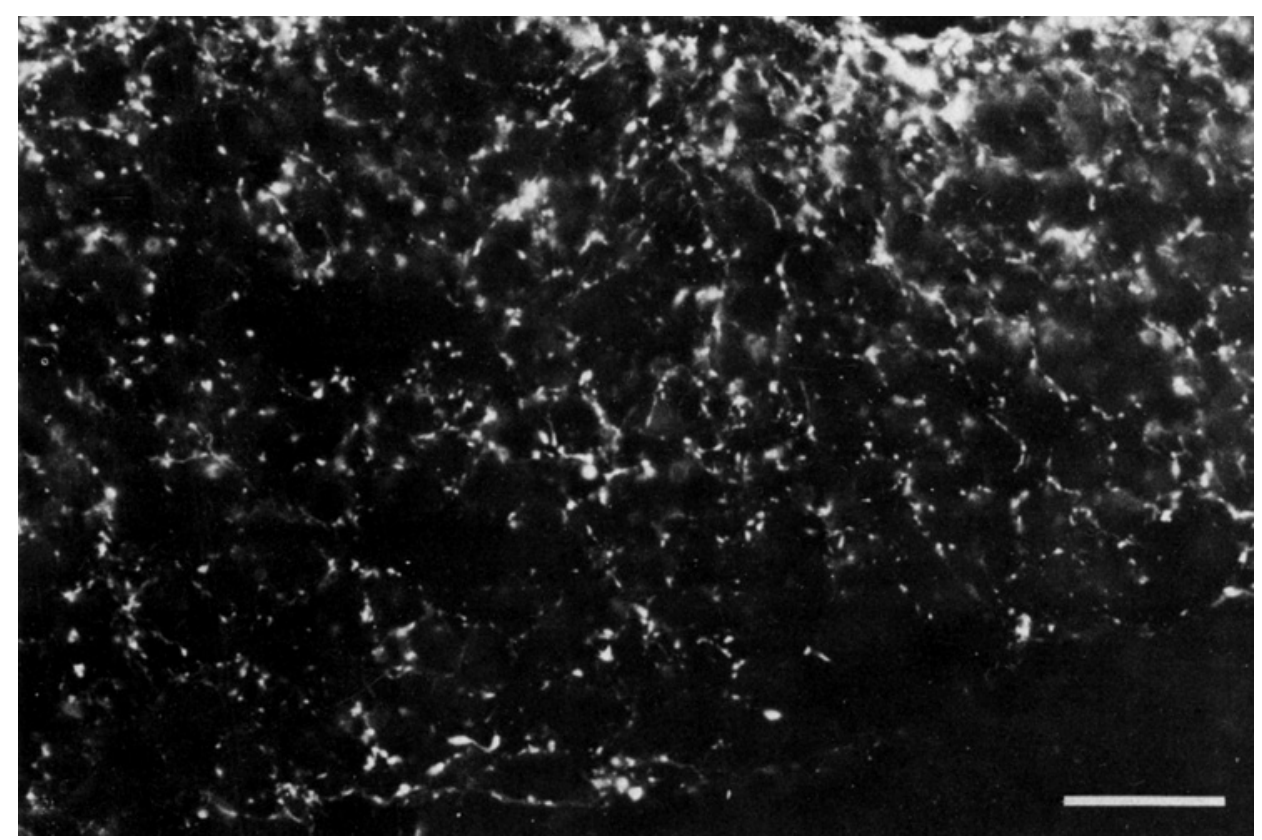

Fig 7. Immunocytochemical localization of NPY-containing fibers in the intermediate lobe of the frog pituitary. Sagittal section of the intermediate lobe stained with anti-NPY serum. White bar $25 \mu \mathrm{m}$. (From Danger JM et al, Life Sci 39, 1183-1192, 1986; with permission).

The first demonstration that NPY is actually involved in the regulation of melanotropin secretion was provided in the frog (Danger et al, 1986). This study was conducted by means of the perifusion technique, which is a dynamic incubation system used to investigate in vitro the kinetics of the responses of various tissues to exogenous secretagogues. The release of $\alpha$-MSH from the pars intermedia of the pituitary was monitored using a sensitive and highly specific radioimmunoassay technique (Vaudry et $a l, 1978$ ). Using this model, it was found that administration of graded concentrations of synthetic (porcine) NPY induces a dose-dependent inhibition of $\alpha$-MSH secretion from whole pituitaries of Rana ridibunda (figure 9). Half-maximum inhibition was observed with a dose of $5 \times 10^{-8} \mathrm{M}$. These results have since been confirmed in 2 other amphibian species, the frog Rana pipiens (Kraicer et al, 1988) and the toad Xenopus laevis (Verburg van Kemenade et al, 1987a). In this latter species, it was observed that NPY inhibits $\alpha$-MSH release without affecting the biosynthesis or processing of the precursor pro-opiomelanocortin; in the newt Triturus cristatus, which lacks NPY innervation of the pars intermedia, NPY has no effect on $\alpha$-MSH secretion (Danger et al, 1989). A comparative study has shown that while NPY inhibits $\alpha$ MSH release from the pars intermedia of anurans, it has no effect on $\alpha$-MSH secretion in the rat (Kraicer et al, 1988). This is in agreement with the lack of NPY innervation (as well as NPY binding sites) in the pars intermedia of the rat. 


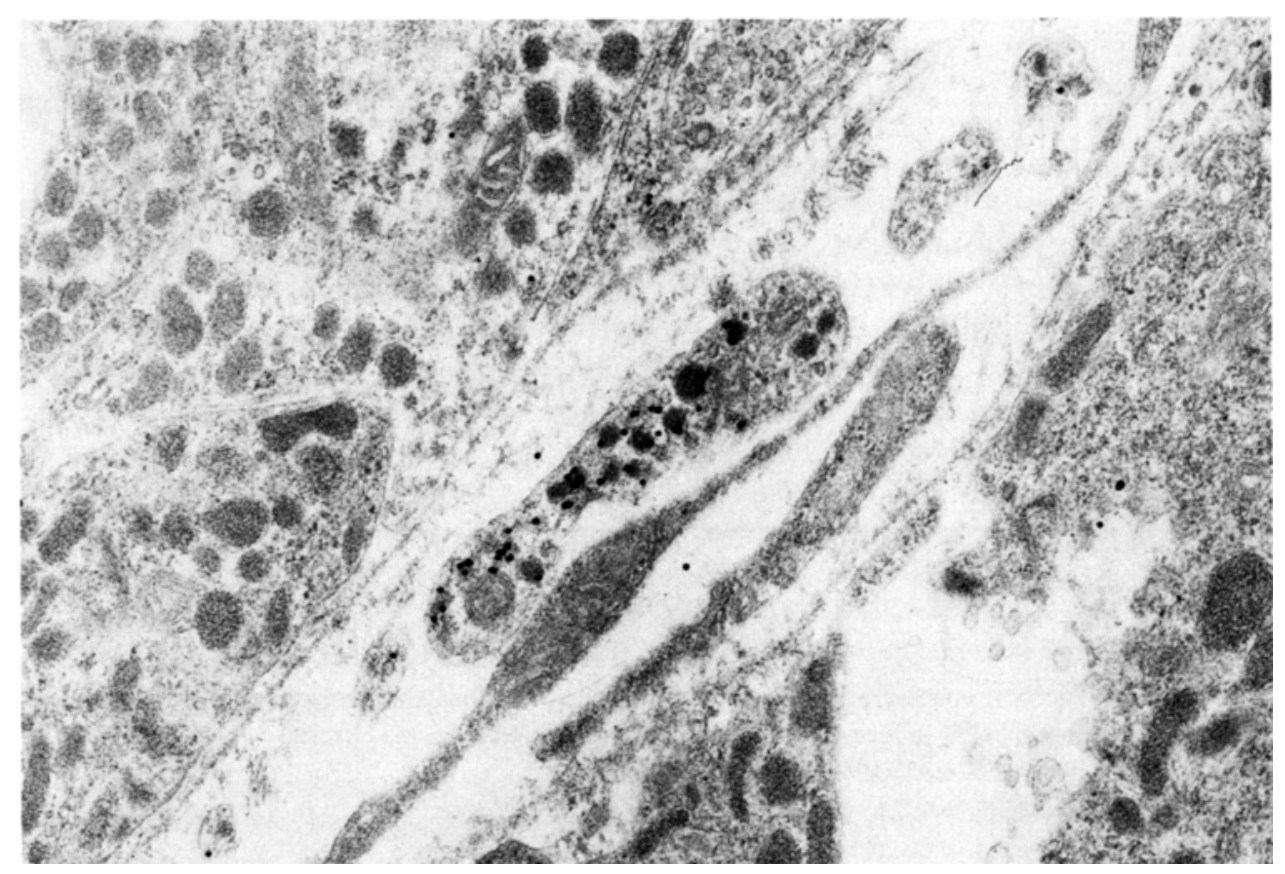

Fig 8. Immunoelectron-microscopic localization of NPY in the frog intermediate lobe. Immunostaining is restricted to a nerve fiber coursing between parenchymal cells. The gold particles are located in dense core vesicles; $(\times 38,000)$. (From Danger JM et al, Life Sci 39, 1183-1192, 1986; with permission).

Symmetrically, in the goldfish, the intermediate lobe is richly innervated by NPY fibers (Pontet et al, 1989) and NPY modulates $\alpha$-MSH secretion (Fryer et $a l, 1989)$. Using several NPY short chain analogues and other members of the PP family, the structure-activity relationship of NPY has been investigated. The results show that the bioactive determinant of NPY is located in the C-terminal part of the molecule (Danger et al, 1987). Two classical neurotransmitters (ie dopamine and GABA) are also potent inhibitors of melanotropic cell activity (Tonon et al, 1983; Adjeroud et al, 1986a, b; Verburg van Kemenade et al, 1986a, b, 1987b). In order to determine whether NPY acts directly on pituitary melanotrophs or presynaptically on dopamine or GABA-containing nerve fibers, the effect of NPY was investigated during prolonged administration of haloperidol and bicuculline. The inhibitory effect of NPY is not affected by the dopaminergic and GABAergic antagonists (Danger et al, 1986). In addition, NPY inhibits $\alpha$ MSH secretion from acutely dispersed pars intermedia cells (Danger et al, 1990). Using the patch-clamp technique, we have recently observed that NPY induces hyperpolarization and inhibition of spontaneous action potential firing (unpublished data). All these experiments demonstrate that NPY exerts its effect 


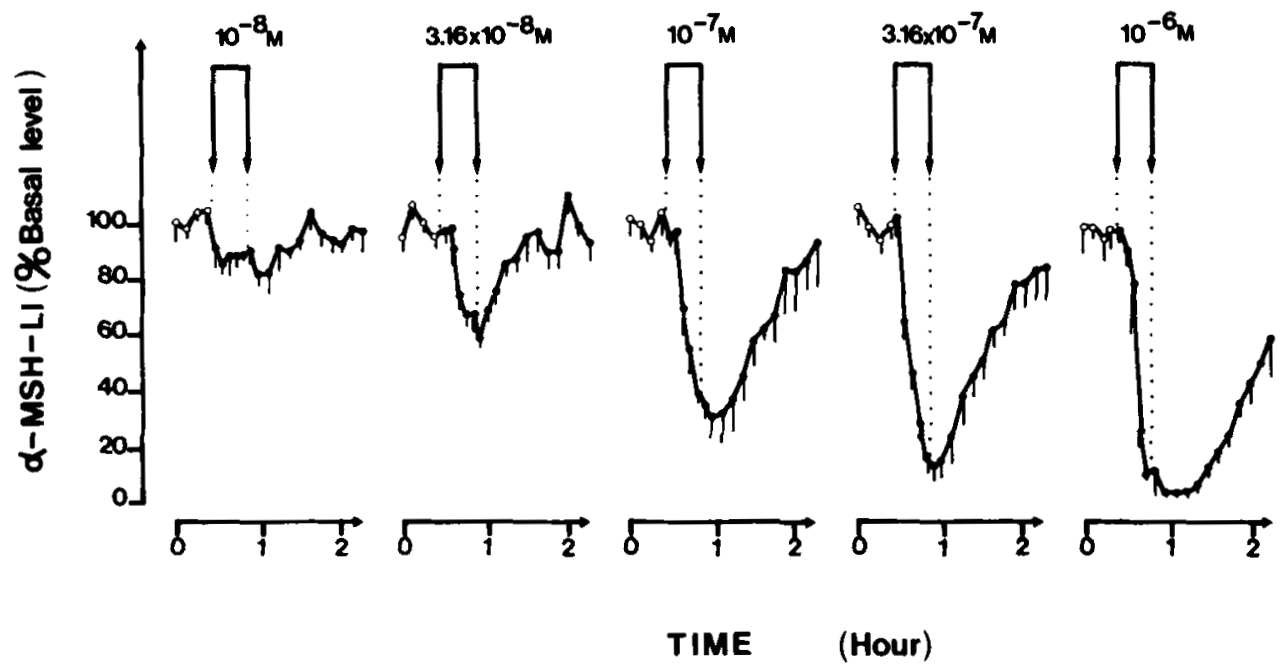

Fig 9. Effect of graded concentrations of NPY on-MSH secretion from isolated perifused frog neurointermediate lobes. NPY induces a dose-dependent inhibition of $\alpha$-MSH release (From Danger JM et al, Life Sci 39, 1183-1192, 1986; with permission).

by acting directly on pituitary melanotrophs. In vivo experiments have shown that administration of NPY to freely moving Xenopus causes a marked melanophore aggregation in black background adapted animals (unpublished data), suggesting that NPY plays a physiological role in the regulation of the melanotropic function. These data suggest that the neuropeptide NPY may be regarded as a melanotropin-release inhibiting factor in non-mammalian vertebrates.

\section{Conclusion}

In conclusion, it now appears that the regulatory peptide NPY, which is highly concentrated and widely distributed in the brain and in the sympathetic nervous system of all vertebrates, can be regarded as a potential neurotransmitter. NPY likely mediates a number of physiological and behavioral processes both at the level of the central nervous system and in peripheral tissues. In particular, NPY is a hypophysiotropic neurohormone which plays a pivotal role in the regulation of gonadotropin secretion by anterior pituitary cells and melanotropin secretion by pars intermedia cells. 


\section{Acknowledgments}

This research was supported by research grants from INSERM (86-4016), France-Québec exchange program (SB7), the European Community (ST1-084-JC and ST2J-0468-C) and the Conseil Régional de Haute-Normandie. JM Danger was recipient of a fellowship from the Ministère de la Recherche et de la Technologie. The authors acknowledge the assistance of $\mathrm{L}$ Matéo and S Moreau for typing the manuscript.

\section{References}

Adams EF, Venetikou MS, Woods CA, Lacoumenta S, Burrin JM (1987) Neuropeptide $\mathrm{Y}$ directly inhibits growth hormone secretion by human pituitary somatotropic tumors. Acta Endocrinol $115,149-154$

Adjeroud S, Tonon MC, Gouteux L, Leneveu E, Lamacz M, Cazin L, Vaudry H, (1986a) In vitro study of frog (Rana ridibunda Pallas) neurointermediate lobe secretion by use of a simplified perifusion system. IV. Interaction between dopamine and thyrotropin-releasing hormone on $\alpha$-melanocyte stimulating hormone secretion. Gen Comp Endocrinol 64, 428-434

Adjeroud S, Tonon MC, Lamacz M, Leneveu E, Stoeckel ME, Tappaz ML, Cazin L, Danger JM, Bernard C, Vaudry H (1986b) Gabaergic control of $\alpha$-melanocyte-stimulating hormone $(\alpha$ MSH) release by frog neurointermediate lobe in vitro. Brain Res Bull 17, 717-724

Adrian TE, Allen JM, Terenghi $G$, Bacarese-Hamilton AJ, Brown MJ, Polak JM, Bloom SR (1983) Neuropeptide $\mathrm{Y}$ in phaeochromocytomas and ganglioneuroblastomas. Lancet ii, 540-542

Albers HE, Ferris CF (1984) Neuropeptide $\mathrm{Y}$ : role in light-dark cycle entrainment of hamster circadian rhythms. Neurosci Lett 50, 163-168

Allen JM, Adrian TE, Allen JM, Tatemoto K, Crow TJ, Bloom SR,
Polak JM (1983) Neupeptide Y distribution in the rat brain. Science 22, 877-879

Allen JM, Ferrier IN, Roberts GW, Cross AJ, Adrian TE, Crow TJ, Bloom SR (1984a) Elevation of neuropeptide $Y$ (NPY) in substantia innominata in Alzheimer's type dementia. $J$ Neurol Sci 64, 325-331

Allen JM, McGregor GP, Woodhams PL, Polak JM, Bloom SR (1984b) Ontogeny of a novel peptide, neuropeptide $Y$ (NPY) in rat brain. Brain Res 303, 197-200

Allen JM, Novotny J, Martin J, Heinrich G (1987) Molecular structure of mammalian neuropeptide $\mathrm{Y}$ : Analysis by molecular cloning and computer-aided comparison with crystal structure of avian homologue. Proc Natl Acad Sci USA 84, 2532-2536

Allen YS, Adrian TE, Allen JM, Tatemoto K, Crow TJ, Bloom SR, Polak JM (1983) Neuropeptide Y distribution in the rat brain. Science 221 , 877-879

Bai FL, Yamano M, Shiotani Y, Emson PC, Smiths AD, Powell JF, Tohyama M (1985) An arcuato-paraventricular and dorsomedial hypothalamic neuropeptide Y-containing system which lacks noradrenaline in the rat. Brain Res 331, 175-175

Beal MF, Chatta GK, Matin JB (1986) A comparison of regional somatostatin and neuropeptide $\mathrm{Y}$ distribution in rat 
striatum and brain. Brain Res 377 , 240-245

Boel E, Schwartz TW, Norris KE, Fiil NP (1984) A cDNA encoding a small common precursor for human pancreatic polypeptide and pancreatic icosapeptide. $E M B O$ J 3, 909-912

Breton B, Milolajckyk T, Danger JM, Gonnet F, Vaudry H (1989) Neuropeptide $\mathrm{Y}$ modulates in vitro gonadotropin release from rainbow trout pituitary gland. Fish Physiol Biochem 7, 77-83 Caillez D, Danger JM, Andersen AC, Polak JM, Pelletier G, Kawamura K, Kikuyama S, Vaudry H (1987a) Neuropeptide Y (NPY)-like immunoreactive neurones in the brain and pituitary of the amphibian Rana catesbeiana. Zool Sci 4, 123-134

Caillez D, Danger JM, Polak JM, Pelletier G, Andersen AC (1987b) Codistribution of neuropeptide $Y$ and its $\mathrm{C}$-terminal flanking peptide in the brain and pituitary of the frog Rana ridibunda. Neurosci Lett 74, 163-168

Card JP, Moore RY (1982) Ventral lateral geniculate efferents to the rat suprachiasmatic nucleus exhibit avian pancreatic polypeptide-like immunoreactivity. J Comp Neurol 206, 390-398

Card JP, Brecha N, Moore RY (1983) Immunohistochemical localization of avian pancreatic polypeptide-like immunoreactivity in the rat hypothalamus. $J$ Comp Neurol 217, 123-126

Carter DA, Vallejo M, Lightman SL (1985) Cardiovascular effects of neuropeptide $Y$ in the nucleus tractus solitarius of rats: relationship with noradrenaline and vasopressin. Peptides 6, 421-425

Chabot JG, Enjalbert A, Pelletier G, Dubois PM, Morel G (1988) Evidence for a direct action of neuropeptide $\mathrm{Y}$ in the rat pituitary gland. Neuroendocrinology 47, 511-517

Chan-Palay V, Yasargil G (1986) Immunocytochemistry of human brain tissue with a polyclonal antiserum against neuropeptide Y. Anat Embryol 174, 27-33 Chan-Palay V (1987) Somatostatin immunoreactive neurons in the human hippocampus and cortex shown by immunogold/silver intensification on vibratome sections: coexistence with neuropeptide $\mathrm{Y}$ neurons and effects in Alzheimer-type dementia. J Comp Neurol 260, 201-233

Chan-Palay V (1988) Techniques for the simultaneous demonstrations of neuropeptide $\mathrm{Y}$ gene expression and peptide storage in single neurons of the human brain. Histochemistry 90, 123-127

Charmantier-Daures $\mathbf{M}$, Danger JM, Netchitailo P, Pelletier G, Vaudry H (1987) Mise en évidence immunocytochimique de substances apparentées au facteur natriurétique auriculaire et au neuropeptide $\mathrm{Y}$ dans les pédoncules oculaires de Homarus gammarus (Crustacea, decapoda). CR Acad Sci (Paris) 305, 479-483

Chronwall BM, Chase TN, O'Donohue TL (1984) Coexistence of neuropeptide $\mathrm{Y}$ and somatostatin in rat and human cortical and rat hypothalamic neurons. Neurosci Lett 52, 213-217

Chronwall BM (1985) Anatomy and physiology of neuroendocrine arcuate nucleus. Peptides 6, 1-11

Chronwall BM, Dimaggio DA, Massari VJ, Pickel VM, Rugiero DA, O'Donohue TL (1985) The anatomy of neuropeptide-Y-containing neurons in rat brain. Neuroscience 15, 1159-1181

Ciofi P, Croix D, Tramu G (1988) Colocalization of GHRF and NPY immunoreactivities in neurons of the infundibular area of the human brain. Neuroendocrinology 47, 469-472

Clark JT, Kalra PS, Crowley WR, Kalra SP (1984) Neuropeptide $Y$ and human pancreatic polypeptide stimulate feeding behavior in rats. Endocrinology 115, 427-429 
Clark JT, Kalra PS, Kalra SP (1985) Neuropeptide $Y$ stimulates feeding but inhibits sexual behavior in rats. Endocrinology 117, 2435-2439

Corder R, Emson PC, Lowry P (1984) Purification and characterization of human neuropeptide $\mathrm{Y}$ from adrenal medullary phaeochromocytoma tissue. Biochem J 219, 699-706

Crowley WR, Tessel RE, O'Donohue TL, Adler BA, Kaira SP (1985) Effects of ovarian hormones on the concentrations of immunoreactive neuropeptide $\mathrm{Y}$ in discrete brain regions of the female rat: correlation with serum luteinizing hormone (LH) and median eminence LH-releasing hormone. Endocrinology 117, 1151-1155

Crowley WR, Hassid AI, Kalra SP (1987) Neuropeptide $Y$ enhances the release of luteinizing hormone induced by luteinizing hormone-releasing hormone. Endocrinology 120, 941-945

Crowley WR, Kalra SP (1987) Neuropeptide $\mathrm{Y}$ stimulates the release of luteinizing hormone-releasing hormone from medial basal hypothalamus in vitro: modulation by ovarian hormones. $\mathrm{Neu}$ roendocrinology 46, 97-103

Danger JM, Guy J, Benyamina M, Jégou S, Leboulenger F, Coté J, Tonon MC, Pelletier G, Vaudry (1985) Localization and identification of neuropeptide $\mathrm{Y}$ NPY-like immunoreactivity in the frog brain. Peptides 6, 1225-1236

Danger JM, Leboulenger F, Guy J, Tonon MC, Benyamina M, Martel JC, Saint-Pierre S, Pelletier G, Vaudry $H$ (1986) Neuropeptide $Y$ in the intermediate lobe of the frog pituitary acts as an MSH-release inhibiting factor. Life Sci 39, 1183-1192

Danger JM, Tonon MC, Lamacz M, Martel JC, Saint-Pierre S, Pelletier G, Vaudry H (1987) Melanotropin-release inhibiting action of neuropeptide $\mathrm{Y}$ : structure-activity relationships. Life $\mathrm{Sci}$ $40,1875-1880$
Danger JM, Lamacz M, Mauviard F, Saint-Pierre S, Jenks BG, Tonon MC, Vaudry H (1990) Neuropeptide Y inhibits thyrotropin-releasing hormoneinduced stimulation of melanotropin release from the intermediate lobe of the frog pituitary. Gen Comp Endocrinol 77, 143-149

Danger JM, Perroteau I, Franzoni MF, Fasolo A, Vaudry H (1989) Innervation of the pars intermedia and control of $\alpha$ MSH secretion in the newt. Neuroendocrinology 50, 543-549

Dawbarn D, Hunt SP, Emson PC (1984) Neuropeptide $\mathrm{Y}$ : regional distribution, chromatographic characterization and immunohistochemical demonstration in post mortem human brain. Brain Res 296, 168-173

DeQuidt ME, Emson PC (1986) Distribution of neuropeptide Y-like immunoreactivity in the rat central nervous system. ii. Immunohistochemical analysis. Neuroscience 18, 545-618

Dray A, Nunan L, Wire W (1986) Neuropeptide $\mathrm{Y}$ depresses reflex urinary bladder contraction in rat modifies central activity of opioid agonists. Peptides 7, 323-329

Edvinsson L (1985) Functional role of perivascular peptides in the control of cerebral circulation. Trends Neurosci 3, 126-131

Ekman R, Wahlestedt C, Bottcher G, Sundler F, Hakanson $R$, Panula $P$ (1986) Peptide YY-like immunoreactivity in the central nervous system of the rat. Regul Peptides 6, 157-168

Emson PC, Corder R, Lowry PJ (1984) Demonstration of a neuropeptide Y-like immunoreactivity in human phaeochromocytoma extracts. Regul Peptides 8, 89-94

Everitt BJ, Hökfelt T, Tenerius L, Tatemoto K (1984) Differential co-existence of neuropeptide Y (NPY)-like immunoreactivity with catecholamines in the 
central nervous system of the rat. Neuroscience $2,443-462$

Foster GA, Schultzberg M, Goldstein M (1984) Differential and independent manifestation within co-containing neurons of neuropeptide $\mathrm{Y}$ and tyrosine hydroxylase during ontogeny of the rat central nervous system. Neurochem Int 6, 761-771

Fryer JN (1989) Neuropeptides regulating the activity of goldfish corticotropes and melanotropes. Fish Physiol Biochem (in press)

Fuxe K, Agnati LF, Harfstrand A, Zini I, Tatemoto K, Merlo Pich E, Hökfelt T, Mutt V, Terenius L (1983) Central administration of neuropeptide $Y$ induces hypotension bradypnea and EEG synchronization in the rat. Acta Physiol Scand 118, 189-192

Fuxe K, Agnati LF, Harfstrand A, Janson AM, Neumeyer A, Andersson K, Ruggeri M, Zoli M, Goldstein M (1986) Morphofunctional studies on the neuropeptide $\mathrm{Y} /$ adrenaline co-storing terminal systems in the dorsal cardiovascular region of the medulla oblongata. Focus on receptorreceptor interactions in cotransmission. Progr Brain Res 68, 303-320

Gall C, Seroogy KB, Brecha N (1986) Distribution of VIP- and NPY-like immunoreactivities in rat main olfactory bulb. Brain Res 374, 389-394

Gaspar P, Berger B, Lesur A, Borsotti JP, Febvret A (1987) Somatostatin 28 and neuropeptide $\mathrm{Y}$ innervation in the septal area and related cortical and subcortical structures of the human brain. Distribution, relationships and evidence for differential coexistence. Neuroscience 22, 49-74

Gibson SJ, Polak JM, Allen JM, Adrian TE, Kelly JS, Bloom SR (1984) The distribution and origin of a novel brain peptide, neuropeptide $\mathrm{Y}$ in the spinal cord of several mammals. J Comp Neurol $227,78-91$
Goldstein M, Kusano N, Adler C, Meller E (1986) Characterization of central neuropeptide $\mathrm{Y}$ receptor binding sites and possible interactions with 2-adrenoceptors. In: Progress in Brain Research (Hökfelt T, Fuxe K, Pernow B, eds) Elsevier, 331-335

Gray TS, Morley JE (1986) Neuropeptide $\mathrm{Y}$ : anatomical distribution and possible function in mammalian nervous system. Life Sci 38, 389-401

Gray TS, O'Donohue TL, Magnuson DJ (1986) Neuropeptide $Y$ innervation of amygdaloid and hypothalamic neurons that project to the dorsal vagal complex in rat. Peptides 7, 341-349

Gustafson EL, Card JP, Moore RY (1986) Neuropeptide $Y$ localization in the amygdaloid complex. J Comp Neurol 251, 349-362

Guy J, Li S, Pelletier G (1988a) Studies on the physiological role and mechanism of action of neuropeptide $\mathrm{Y}$ in the regulation of $\mathrm{LH}$ secretion in the rat. Regul Peptides 23, 209-216

Guy J, Pelletier G, Bosler O (1988b) Serotonin innervation of neuropeptide $Y$ neurons in the rat arcuate nucleus. Neurosci Lett 85, 9-13

Haas AD, George SR (1987) Neuropeptide $Y$ administration acutely increases corticotropin-releasing factor immunoreactivity: lack of effect in other rat brain regions. Life Sci 41, 2725-2731

Harfstrand A (1986) Intraventricular administration of neuropeptide $Y$ (NPY) induces hypotension, bradycardia and bradypnea in the awake unrestrained male rat. Counteraction by NPY-induced feeding behavior. Acta Physiol Scand 128, 121-123

Harfstrand A, Fuxe K, Agnati LF, Benfenati F, Goldstein M (1986) Receptor autoradiographical evidence for high densities of ${ }^{125}$ I-neuropeptide $\mathrm{Y}$ binding sites in the nucleus tractus solitarius of the normal male rat. Acta Physiol Scand 128, 195-200 
Harfstrand A, Fuxe K, Agnati L, Kitayama I, Cintra AO, Janson AM, Kalia $M$, Vanderhaegen $J J$, Goldstein $M$, Terenius (1987a) Intracisternal administration of cholecystokinin-8 counteracts the central cardiovascular effects of adrenaline and NPY. A study based on the coexistence of cholecystokinin, phenylethanolamine $N$-methyltransferase and neuropeptide $\mathrm{Y}$ immunoreactivity in neurons of the nucleus tractus solitarius. Neurochem 4, 481-494

Harfstrand A, Fuxe K, Terenius L, Kalia M (1987b) Neuropeptide Y-immunoreactive perikarya and nerve terminals in the rat medulla oblongata: relationship to cytoarchitecture and catecholaminergic cell group. J Comp Neurol 260, 20-35

Harrington ME, Nance DM, Rusak B (1985) Neuropeptide Y immunoreactivity in the hamster geniculo-suprachiasmatic tract. Brain Res Bull 15, 465-472

Hendry SHC, Jones EG, Emson PC (1984a) Morphology, distribution and synaptic relations of somatostatin and neuropeptide $\mathrm{Y}$-immunoreactive neurons in rat and monkey neocortex. $J$ Neurosci 4, 2497-2517

Hendry SHC, Jones EG, de Felipe J, Schmechel D, Brandon C, Emson PC (1984b) Neuropeptide-containing neurons of the cerebral cortex are also GABAergic. Proc Natl Acad Sci USA $81,6526-6530$

Hökfelt T, Schultzberg M, Lundberg JM, Fuxe K, Mutt V, Fahrenkrug J, Said SI (1982) Distribution of vasoactive intestinal polypeptide in the central and peripheral nervous systems as revealed by immunocytochemistry. In: Advances in Peptide Hormone Research Series (Said SI, ed) 65-90 Raven Press, New York

Hökfelt T, Lundberg JM, Lagercrantz $H$, Tatemoto K, Mutt V, Lundberg J,
Terenius L, Everitt BJ, Fuxe K, Agnati L, Goldstein M (1983a) Occurrence of neuropeptide Y (NPY)-like immunoreactivity in catecholamine neurons in the human medulla oblongata. Neurosci Lett 36, 217-222

Hökfelt T, Lundberg JM, Tatemoto K, Mutt W, Terenius L, Polak, Bloom S, Sasek C, Elde R, Goldstein (1983b) Neuropeptide Y (NPY)- and FRMFamide neuropeptide-like immunoreactivities in catecholamine neurons of the rat medulla oblongata. Acta Physiol Scand 117, 315-318

Holets VR, Hökfelt T, Terenius L, Goldstein $M$ (1985) Differential projections of locus coeruleus neurons containing tyrosine hydroxylase and neuropeptide $\mathrm{Y}$ and/or galanin. Soc Neurosci 145

$\mathrm{Hu}$ H, Rao J, Prasad C, Jayaraman A (1987) Localization of neuropeptide Ylike immunoreactivity in the cat hypothalamus. Peptides 8, 569-573

Hunt SP, Emson PC, Gilbert R, Goldstein M, Kimmell JR (1981) Presence of avian pancreatic polypeptide-like immunoreactivity in catecholamine and methionine enkephaline-containing neurons within the central nervous system. Neurosci Lett 21, 125-130

Ivell R, Emson P, Richter D (1984) Human neuropeptide $Y$, somatostatin and vasopressin precursors identified in cell-free translations of hypothalamic mRNA. FEBS Lett 177, 175-178

Jenks BG, Leenders HJ, Verburg-van Kemenade BML, Tonon MC, Vaudry $\mathrm{H}$ (1986) Strategies in the regulation of secretory signals from proopiomelanocortin-producing cells: In: Neuroendocrine Molecular Biology (Fink G, Harmar AJ, McKerns KW, eds) Plenum Press, New York, 281-294

Kalra SP, Crowley WR (1984) Norepinephrine-like effects of neuropeptide $Y$ on $\mathrm{LH}$ release in the rat. Life Sci 35, 1173-1176 
Kerkérian L, Guy J, Lefevre G, Pelletier G (1985) Effects of neuropeptide $Y$ (NPY) on the release of anterior pituitary hormones in the rat. Peptides 6, 1201-1204

Kerkérian L, Pelletier G (1986) Effects of monosodium L-glutamate administration on neuropeptide Y-containing neurons in the rat hypothalamus. Brain Res $369,388-390$

Kerkérian L, Bosler O, Pelletier G, Nieoullon A (1986) Striatal neuropeptide $\mathrm{Y}$ neurons are under the influence of the nigrostriatal dopaminergic pathway: immunohistochemical evidence. Neurosci Lett 66, 106-112

Khorram O, Pau KYF, Spies HG (1987) Bimodal effects of neuropeptide $Y$ on hypothalamic release of gonadotropinreleasing hormone in conscious rabbits. Neuroendrocrinology 45, 290-297

Kimmel JR, Hayden LJ, Pollock HG (1975) Isolation and characterization of a new pancreatic polypeptide hormone.

$J$ Biol Chem 250, 9369-9376

Köhler C, Eriksson L, Davies S, ChanPalay V (1986a) Neuropeptide Y innervation of the hippocampal region in the rat and monkey brain. J Comp Neurol 244, 384-400

Köhler C, Smilowska M, Eriksson LG, Chan-Palay V, Davies S (1986b) Origin of the neuropeptide $\mathrm{Y}$ innervation of the rat retro-hippocampal region. Neurosci Lett 65, 287-292

Köhler C, Eriksson LG, Davies S, ChanPalay V (1987) Co-localization of neuropeptide tyrosine and somatostatin immunoreactivity in neurone of individual subfields of the rat hippocampal region. Neurosci Lett 78, 1-6

Kordon C, Glowinski J (1972) Role of hypothalamic monoaminergic neurons in the gonadotropin release regulating mechanisms. Neuropharmacology 11, 153-162

Kraicer J, Lussier B, Kotanen S, Moor BC (1988) Neuropeptide $Y$ does not inhibit the release of $\alpha$-MSH from the pars intermedia of the rat adenohypophysis. Can J Physiol Pharmacol $66,318-320$

Krukoff TL (1987) Neuropeptide Y-like immunoreactivity in cat spinal cord with special reference to autonomic areas. Brain Res 415, 300-308

Kuenzel WJ (1988) Neuropeptide Y : brain localization and central effects on plasma insulin levels in chicks. Physiol Behav 44, 669-678

Larhammar D, Ericsson A, Persson $\mathbf{H}$ (1987) Structure and expression of the rat neuropeptide Y gene. Proc Natl Acad Sci USA 84, 2068-2072

Leblanc GG, Trimmer BA, Landis SC (1987) Neuropeptide Y-like immunoreactivity in rat cranial parasympathetic neurons, Co-existence with vasoactive intestinal peptide and choline acetyltransferase. Proc Natl Acad Sci USA 84, 3511-3515

Léger L, Charnay Y, Danger JM, Vaudry H, Dubois PM, Jouvet M (1987) Mapping of neuropeptide Y-like immunoreactivity in the feline hypothalamus and hypophysis. J Comp Neurol 255, 283-292

Levine AS, Morley JE (1984) Neuropeptide $\mathrm{Y}$ : a potent inducer of consummatory behavior in rats. Peptides 5, 1025-1029

Lin TM, Chance RE (1972) Spectrum gastrointestinal actions of a new bovine pancreas polypeptide (BPP). Gastroenterology 62, Abst 852

Lin TM, Chance RE (1974) Gastrointestinal actions of a new bovine pancreatic polypeptide (BPP). In: Endocrinology of the Gut (Che WY, Brooks FP, eds) $143-145$

Liposits Z, Siever L, Paull WK (1988) Neuropeptide $Y$ and ACTH-immunoreactive innervation of corticotropin releasing factor (CRF)-synthesizing neurons in the hypothalamus of the rat. An immunocytochemical analysis at the 
light and electron microscopic levels. Histochemistry 88, 227-234

Loren I, Alumets J, Hakanson R, Sundler F (1979) Immunoreactive pancreatic polypeptide (PP) occurs in the central and peripheral system: preliminary immunocytochemical observations. Cell Tissue Res 200, 179-186

Lundberg JM, Hökfelt T, Anggard A, Kimmel J, Goldstein M, Markey $K$ (1980) Coexistence of an avian pancreatic polypeptide (APP)-immunoreactive substance and catecholamines in some peripheral and central neurons. Acta Physiol 110, 107-109

Lundberg JM, Terenius L, Hökfelt T, Tatemoto K (1984) Comparative immunohistochemical and biochemical analysis of pancreatic polypeptide-like peptides with special reference to presence of neuropeptide $\mathrm{Y}$ in central and peripheral neurons. $J$ Neurosci 4 , 2376-2386

Martel JC, Fournier A, Saint-Pierre S, Quirion R (1990) Quantitative autoradiographic distribution of [ $\left.^{125} \mathrm{I}\right]$ BoltonHunter neuropeptide $\mathrm{Y}$ receptor binding sites in rat brain. Comparison with [ ${ }^{125}$ I]peptide YY receptor sites. $J \mathrm{Neu}$ rosci (in press)

Massari VJ, Chan J, Chronwall B, O'Dohonue TL, Pckel VM (1984) Neuropeptide $\mathrm{Y}$ in the rat nucleus accumbens: ultrastructural localization and synaptic interation with GABAergic neurons. Soc Neurosci 537

McDonald JK, Lumpkin MD, Samson WK, McCann SM (1985a) Neuropeptide $Y$ affects secretion of luteinizing hormone and growth hormone in ovariectomized rats. Proc Natl Acad Sci USA 82, 561-564

McDonald JK, Lumpkin MD, Samson WK, McCann SM (1985b) Pancreatic polypeptides affect luteinizing and growth hormone secretion in rats. Peptides 6, 79-84
McDonald JK, Koening JI, Gibbo DM, Collin P, Noe BD (1987) High concentrations of neuropeptide $\mathrm{Y}$ in pituitary portal blood of rats. Neuroendocrinology 46, 538-541

Minth CD, Bloom SR, Polak JM, Dixon JE (1984) Cloning, characterization and DNA sequence of human cDNA encoding neuropeptide tyrosine. Proc Natl Acad Sci USA 81, 4577-4581

Minth CD, Andrews PC, Dixon JE (1986) Characterization, sequence and expression of the cloned human neuropeptide Y gene. J Biol Chem 261, 11974-11979

Moltz JH, Mc Donald JK (1985) Neuropeptide $\mathrm{Y}$ : Direct and indirect action on insulin secretion in the rat. Peptides 6, 1155-1159

Moore RY, Gustafson EL, Card PJ (1984) Identical immunoreactivity of afferents to the rat suprachiasmatic nucleus with antisera against avian pancreatic polypeptide, molluscan cardioexcitatory peptide and neuropeptide Y. Cell Tissue Res 236, 41-46

Morioka $H$, Inui A, Suenaga K, Mizuno N, Baba S (1984) Effects of intracerebroventricular injection of neuropeptide YY (PYY) and pancreatic polypeptide (PP) on thermoregulation in conscious canine. Digest Dis Sci 29, 555

Morley JE (1987) Neuropeptide regulation of appetite and weight. Endocrine Rev 3, 256-287

Morley JE, Hernandez EN, Flood JF (1987) Neuropeptide $Y$ increases food intake in mice. Am $J$ Physiol 253, 516-522

Nakajima T, Yashima Y, Nakamura K (1986) Quantitative autoradiographic localization of neuropeptide $Y$ receptors in the rat lower brainstem. Brain Res $380,144-150$

Nizielski SE, Gosnell BA, Morley JE, Levine AS (1985) Neuropeptide Y increases feeding in the ground squirrel. Fed Proc 44, 545A 
O'Hare MMT, Tenmoku S, Aakerlund L, Hilsted L, Johnsen A, Schwartz TW (1988) Neuropeptide $Y$ in guinea pig, rabbit, rat and man. Identical amino acid sequence and oxidation of methionine-17. Regul Peptides 20, 293-304

Parott RF, Heavens RP, Baldwin BA (1986) Stimulation of feeding in the satiated pig by intracerebro-ventricular injection of neuropeptide Y. Physiol Behav 36, 523

Pelletier G (1980) Immunohistochemical localization of LHRH in brain at both light and electron microscopic levels. In: Advances in Sex Hormone Research, Vol 4 (Thomas JA, Singhal RL, eds) Urban and Schwarzenberg, Baltimore, 187-212

Pelletier G, Désy L, Kerkerian L, Coté J (1984a) Immunocytochemical localization of neuropeptide $Y$ (NPY) in the human hypothalamus. Cell Tissue Res 238, 203-205

Pelletier G, Guy J, Allen YS, Polak JM (1984b) Electron microscope immunocytochemical localization of neuropeptide $\mathrm{Y}$ (NPY) in the rat brain. Neuropeptides 4, 319-324

Perroteau I, Danger JM, Biffo S, Pelletier G, Vaudry H, Fasolo A (1988) Distribution and characterization of neuropeptide Y-like immunoreactivity in the brain of the crested newt. J Comp Neurol 275, 309-325

Pontet A, Danger JM, Dubourg P, Pelletier G, Vaudry H, Kah O (1989) Distribution and characterization of a neuropeptide Y-like factor in the brain and pituitary of the goldfish. Cell Tissue Res 255, 529-538

Rémy C, Guy J, Pelletier G, Boer H (1988) Immunohistochemical demonstration of a substance related to neuropeptide $Y$ and FMRF amide in the cephalic and thoracic nervous systems of the locust Locusta migratoria. Cell Tissue Res 254, 189-195
Reuss S, Schroder H (1987) Neuropeptide $\mathrm{Y}$ effects on pineal melatonin synthesis in the rat. Neurosci Lett 74, 158-162

Rodriguez-Sierra JF, Jacobowitz DM, Blacke CA (1987) Effects of neuropeptide $\mathrm{Y}$ on LH, FSH and TSH release in male rats. Peptides 8, 539-542

Sabatino FD, Murnane JM, Hoffman RA, McDonald JK (1987) Distribution of neuropeptide Y-like immunoreactivity in the hypothalamus of the adult golden hamster. J Comp Neurol 257, 93-105

Sahu A, Kalra SP, Crowley WR, O'Donohue TL, Kalra PS (1987) Neuropeptide $Y$ levels in microdissected regions of the hypothalamus and in vitro release in response to $\mathrm{KCl}$ and prostaglandin $\mathrm{E}_{2}$ : effects of castration. Endocrinology 120, 1831-1836

Sahu A, Kalra SP, Crowley WR, Kalra PS (1989) Testosterone raises neuropeptide $\mathrm{Y}$ concentration in selected hypothalamic sites and in vitro release from the medial basal hypothalamus of castrated male rats. Endocrinology 124, 410-414

Sasek CA, Elde RP (1985) Distribution of neuropeptide $\mathrm{Y}$-like immunoreactivity and its relationship to FMRF-amide-like immunoreactivity in sixth lumbar and first sacral spinal cord segments of the rat. $J$ Neurosci 5, 1729-1739

Sawchenko PE, Swanson LW, Grzanna R, Howe PRC, Bloom SR, Polak JM (1985) Colocalization of neuropeptide $Y$ immunoreactivity in brainstem catecholaminergic neurons that projets to the paraventricular nucleus of the hypothalamus. J Comp Neurol 241, 138-153

Schneider HPG, McCann SM (1970) Mono- and indolamines and control of LH secretion. Endocrinology 86, 1127-1133

Schoofs L, Danger JM, Jégou S, Pelletier G, Huybrechts R, Vaudry H, De Loof A (1988) NPY-like peptides occur in the 
nervous system and midgut of the migratory locust, Locusta migratoria, in the brain of the grey fleshfly, Sarcophaga bullata. Peptides 9, 1027-1036 Schwartz TW, Tager HS (1981) Isolation and biosynthesis of a new peptide from pancreatic islets. Nature 94, 326-329

Schwartz TW, Hansen HF (1984) Isolation of ovine pancreatic icosapeptide: a peptide product containing one cystein residue. FEBS Lett 168, 293-298

Scott JN, McDonald JK, Plemberton JL (1987) Short axon cells of the rat olfactory bulb display NADPH-diaphorase activity neuropeptide Y-like immunoreactivity, and somatostatine-like immunoreactivity. J Comp Neurol 260, 378-391

Sheikh SP, Hakanson R, Schwartz TW (1989) $Y_{1}$ and $Y_{2}$ receptors for neuropeptide Y. FEBS Lett 245, 209-214

Smith Y, Parent A, Kerkerian L, Pelletier $G$ (1985) Distribution of neuropeptide $Y$ immunoreactivity in the basal forebrain and upper brainstem of the squirrel monkey (Saiimiri sciureus). J Comp Neurol 236, 71-89

Smith Y, Parent A (1986) Neuropeptide Y-immunoreactive neurons in the striatum of cat and monkey: morphological characteristics, intrinsic organization and co-localization with somatostatin. Brain Res 372, 241-252

Stanley BG, Leibowitz S (1984) Neuropeptide $Y$ : stimulation of feeding and drinking by injection into the paraventricular nucleus. Life Sci 35, 2635-2642 Stanley BG, Chin AS, Leibowitz SF (1985a) Feeding and drinking elicited by central injection of neuropeptide $\mathrm{Y}$ : evidence for hypothalamic site(s) of action. Brain Res Bull 14, 521-524

Stanley BG, Daniel DR, Chin AS, Leibowitz SF (1985b) Paraventricular injections of peptide YY and neuropeptide $\mathrm{Y}$ preferentially enhance carbohydrate ingestion. Peptides 6, 1205-1211
Steinman JL, Gunion MW, Morley JE (1987) Third and fourth ventricle neuropeptide Y (NPY) stimulates feeding and drinking in rats. Fed Proc 46, 1125

Takeuchi T, Gumucio DL, Yamada T, Meisler MH, Minth CD, Dixon JE, Eddy RE, Shows TB (1986) Gene encoding pancreatic polypeptide and neuropeptide $\mathrm{Y}$ are on human chromosomes 17 and 7. J Clin Invest 77, 1038-1041

Tatemoto K, Mutt V (1982) Isolation and characterization of peptide YY (PYY), a candidate gut hormone that inhibits pancreatic exocrine secretion. Proc Natl Acad Sci USA 79, 2514-2518

Tatemoto K, Calquist M, Mutt V (1982) Neuropeptide $Y$ - a novel brain peptide with structural similarities to peptide YY and pancreatic polypeptide. Nature 296, 659-660

Terenghi G, Polak JM, Hamid Q, O'Brien E, Denny P, Legon S, Dixon J, Minth CD, Palay SL, Yasargil G, Chan-Palay V (1987) Localization of neuropeptide $Y$ mRNA in neurons of human cerebral cortex by means of in situ hybridization with a complementary RNA probe. Proc Natl Acad Sci USA, 84, 7315-7318

Tonon MC, Leroux P, Stoeckel ME, Jegou S, Pelletier G, Vaudry H (1983) Catecholaminergic control of $\alpha$ melanocyte-stimulating hormone ( $\alpha$ MSH) release by frog neurointermediate lobe in vitro: Evidence for direct stimulation of $\alpha-\mathrm{MSH}$ release by thyrotropinreleasing hormone. Endocrinology 12 , 133-141

Ueda S, Kawato M, Sano Y (1986) Identification of neuropeptide $Y$ immunoreactivity in the suprachiasmatic neucleus and the lateral geniculate nucleus of some mammals. Neurosci Lett 68, 7-10

Unden A, Bartfai T (1984) Regulation of neuropeptide Y (NPY) binding by gua- 
nine nucleotides in the rat cerebral cortex. FEBS Lett 177, 125-128

Unden A, Tatemoto K, Mutt V, Bartfai T (1984) Neuropeptide $Y$ receptor in the rat brain. Eur $J$ Biochem 145, 525-530

Vallarino M, Danger JM, Fasolo A, Pelletier G, Saint-Pierre S, Vaudry H (1988) Distribution and characterization of neuropeptide $\mathrm{Y}$ in the brain of an elasmobranch fish, Brain Res 448, 67-76

Vanderhaeghen JJ, Signeau JC, Gepts W (1975) New peptide in the vertebrate CNS reacting with antigastrin antibodies. Nature 257, 604-605

Van Reeth O, Goldman S, Schiffmann S, Verstappen A, Pelletier G, Vaudry H, Vanderhaeghen JJ (1987) Distribution of neuropeptide $\mathrm{Y}$ immunoreactivity in human visual cortex and underlying white matter. Peptides 8, 1107-1117

Vaudry H, Tonon MC, Delarue C, Vaillant R, Kraicer J (1978) Biological and radioimmunological evidence for melanocyte-stimulating hormone (MSH) of extrapituitary origin in the rat brain. Neuroendocrinology 27, 9-24

Verburg-van Kemenade BML, Tappaz M, Paut L, Jenks BG (1986a) GABAergic regulation of melanocyte-stimulating hormone secretion from the pars intermedia of Xenopus laevis: immunocytochemical and physiological evidence. Endocrinology 118, 260-267

Verburg-van Kemenade BML, Tonon MC, Jenks BG, Vaudry H (1986b) Characterization of dopamine receptors in the pars intermedia of the amphibian Xenopus laevis. Neuroendocrinology 44, 446-456

Verburg-van Kemenade BML, Jenks BG, Danger JM, Vaudry H, Pelletier G, Saint-Pierre S (1987a) A NPY-like peptide may function as MSH-release inhibiting factor in Xenopus laevis. Peptides 8, 61-67 "'erburg-van Kemenade BML, Jenks BG, Lenssen FJA, Vaudry H (1987b) Characterization of GABA receptors in the neurointermediate lobe of the amphibian Xenopus laevis. Endocrinology $120,622-628$

Vincent SR, Johansson $O$, Hökfelt $T$, Skirboll L, Elde RP, Terenius L, Kimmel J, Goldstein M (1982) Co-existence of somatostatin- and avian pancreatic polypeptide (APP)-like immunoreactivity in some forebrain neurons. Neuroscience 7, 439-446

Wahle P, Meyer G, Albus K (1986) Localization of NPY-immunoreactivity in the cat's visual cortex. Exp Brain Res 61, 364-374

Wahlestedt C, Skagerberg G, Ekman R, Heilig M, Sundler F, Hakanson R (1987) Neuropeptide Y (NPY) in the area of the hypothalamic paraventricular nucleus activates the pituitaryadrenocortical axis in the rat. Brain Res 477, 33-38

Walker MW, Miller RJ (1988) ${ }^{125} \mathrm{I}$ neuropeptide $\mathrm{Y}$ and ${ }^{125} \mathrm{I}$-peptide $\mathrm{YY}$ bind to multiple receptor sites in rat brain. Mol Pharmacol 34, 779-792

Willoughby JO, Blessing WW (1987) Neuropeptide $Y$ injected into the supraoptic nucleus causes secretion of vasopressin in the unanesthetized rat. Neurosci Lett $75,17-22$

Yamato H, Nata K, Okamoto H (1986) Mosaic evolution of prepropancreatic polypeptide. $J$ Biol Chem 261, 6156-6159

Zini I, Merlo, Pich E, Fuxe K, Lenzi PL, Agnati LF, Harfstrand A, Mutt V, Tatemoto K, Mos, Cara M (1984) Action of centrally administered neuropeptide $Y$ on EGG activity in different rat strains and in different phases of their circadian cycle. Acta Physiol Scand 122, 71-77 